\title{
SCP-Containing R20 Neurons Modulate Respiratory Pumping in Aplysia
}

\author{
A. Alevizos, ${ }^{1,3,4}$ K. R. Weiss, ${ }^{1,2,4}$ and J. Koester ${ }^{1,2,4}$ \\ ${ }^{1}$ Center for Neurobiology and Behavior, ${ }^{2}$ Department of Psychiatry, and ${ }^{3}$ Department of Physiology and Cellular \\ Biophysics, College of Physicians and Surgeons, Columbia University, New York, New York 10032, and ${ }^{4}$ The New York \\ State Psychiatric Institute, New York, New York 10032
}

\begin{abstract}
Respiratory pumping in Aplysia consists of transient, synchronous pumping actions of the gill, siphon, mantle shelf, and parapodia. This behavior has previously been shown to be driven by a network of coupled interneurons in the abdominal ganglion, the R25 and the L25 cells. We describe here a pair of electrically coupled cells, the R20 cells, which when active can initiate respiratory pumping or increase its spontaneous rate of occurrence. This action is mediated by a slow, long-lasting excitation of the endogenous burst mechanism of the cells in the R25/L25 network. The R20 cells, which are located in the abdominal ganglion, also make slow inhibitory connections to the RB cells and to the RG cells in that ganglion, and to the gill motoneurons in the branchial ganglion. The $R 20$ cells are immunoreactive to $\mathrm{SCP}_{\mathrm{B}}$, a molluscan neuropeptide. Biochemical purification studies demonstrate that each of the R20 cells synthesizes not only $\mathrm{SCP}_{B}$, but also $\mathrm{SCP}_{\mathrm{A}}$, a closely related molecule known to be encoded by the same gene as $S_{C P}$. The R20 cells also synthesize in abundance several other low-molecular-weight, methionine-containing peptides. The excitatory actions of the R20 cells on the R25/L25 network are mimicked by SCPA and $\mathrm{SCP}_{\mathrm{B}}$. However, the inhibitory actions of the R20 cells on the RB cells, the RG cells, and on the cells of the branchial ganglion are not mimicked by the SCPS. Thus, the data support the hypothesis that the R20 cells release $\mathrm{SCP}_{A}$ and $\mathrm{SCP}_{\mathrm{B}}$ and at least one other unidentified transmitter.
\end{abstract}

Respiration in Aplysia is facilitated by a steady rostrocaudal flow of seawater driven past the surfaces of the gill by the cilia on the gill, the mantle shelf, and the siphon. The steady current of seawater driven by cilia through the mantle cavity is supplemented periodically by respiratory pumping, which consists of synchronous contractions of the gill, siphon, mantle shelf, and parapodia. The frequency of respiratory pumping is highly variable, occurring at intervals ranging from about $1 / \mathrm{min}$ to $1 / \mathrm{hr}$. During each pumping episode, which lasts only a few seconds,

\footnotetext{
Received Nov. 8, 1988; revised Feb. 1, 1989; accepted Feb. 2, 1989.

We thank Renata Tennenbaum for performing the HPLC analyses, the Howard Hughes Medical Institute Marine Resources Facility at the Woods Hole Oceanographic Institute for supplying animals, and E. C. Cropper and I. Kupfermann for critically reviewing an earlier draft of this paper. This work was supported by grants from NIH (NS14385) and NIMH (MH367330; MH35564), and by the Hellenic University Club of New York.

Correspondence should be addressed to Dr. John Koester, Center for Neurobiology and Behavior, The New York State Psychiatric Institute, 722 West 168th Street, New York, NY 10032.

Copyright (C) 1989 Society for Neuroscience $0270-6474 / 89 / 093058-14 \$ 02.00 / 0$
}

the heart is inhibited, seawater is forced out of the mantle cavity, and blood is forced from the gill, through the heart and into the arterial system. When the mantle organs relax, the mantle cavity refills with oxygenated seawater and the gill refills with blood. It has been suggested that this action may promote gaseous exchange across the surface of the gill (Byrne and Koester, 1978; Croll, 1985) and, under certain conditions, may help to cleanse the mantle cavity of debris or secretory material (Kupfermann and Kandel, 1969; Walters and Erickson, 1986).

Respiratory pumping can be generated both spontaneously and in a triggered mode. The frequency of spontaneously occurring respiratory pumping is increased by food arousal and during feeding (Koester et al., 1979; Eberly et al., 1981) and in response to decreased $\mathrm{pO}_{2}$ or increased $\mathrm{pCO}_{2}$ in the ambient seawater (Croll, 1985; Kanz and Quast, 1986). Similar pumping movements can be triggered in 3 ways: (1) by tactile stimuli to the mantle organs, in which case the behavior contributes to defensive withdrawal (Pinsker et al., 1970); (2) by the central program for locomotion, which triggers a single pumping episode with each cycle of the stepping program (Hening, 1982); and (3) by noxious stimulation of the head or tail, which elicits a brief train of several pumping episodes that lasts for about 5$10 \mathrm{~min}$ (Walters and Erickson, 1986; Frost, 1987). Both the triggered and the spontaneous episodes of the behavior exhibit simple forms of behavioral plasticity (Eberly and Pinsker, 1984; Hawkins et al., 1985).

There are dozens of identified motoneurons in the branchial, abdominal, and pedal ganglia that mediate respiratory pumping (reviewed by Koester and Kandel, 1977; Hening, 1982). Two symmetrical clusters of interneurons located in the abdominal ganglion have been shown to project to the motoneurons and to act as trigger cells for the behavior. These trigger cclls, which originally were known as the Interneuron II cells (Kandel et al., 1967), consist of a cluster of R 25 cells in the right hemi-ganglion (Koester, 1983) and a symmetrically located cluster of L25 cells in the left hemiganglion (Byrne, 1983). Each cluster is made up of about 15 cells. There are extensive electrical and chemical synapses between the cells in these 2 clusters. Synchronous activity in the R25/L25 network initiates and coordinates the various components of spontaneous episodes of respiratory pumping, as well as the episodes triggered by stimuli to the mantle organs (Byrne, 1983; Koester, 1983).

The frequency of spontaneous activity of the R25/L25 network varies considerably across animals and within animals, just as the frequency of respiratory pumping varies in the intact animal (Eberly et al., 1981). In order to begin to analyze the sources of this spontaneous variability, as well as the mecha- 
nisms by which environmental stimuli influence the frequency of occurrence of the behavior, we surveyed the ganglion for cells that might exert a modulatory action on the R25/L25 network. We describe here a pair of identified neurons in the abdominal ganglion that can both trigger respiratory pumping and modulate the frequency of spontaneous, rhythmically occurring episodes of the behavior. Some of these results were published earlier in abstract form (Koester, 1983; Alevizos et al., 1988).

\section{Materials and Methods}

Animals. Specimens of Aplysia californica weighing 40-250 gm were supplied by Marinus, Long Beach, CA; Sea Life Supply, Sand City, CA; and the Howard Hughes Medical Institute Marine Resources Facility at the Woods Hole Oceanographic Institute, Woods Hole, MA. Animals were maintained in an aquarium containing artificial seawater (ASW, Instant Ocean) at $15^{\circ} \mathrm{C}$ until used. The results described below were obtained from 171 R20 cells in 130 ganglia.

Electrophysiology. In most experiments the abdominal ganglion was removed from the animal and pinned to the Silastic-coated bottom of the recording chamber, which was filled with ASW. In addition, 2 types of semi-intact preparations also were used in some experiments: (1) the mantle organs (heart, gill, and siphon) and the branchial ganglion were dissected, along with the peripheral nerves that connect them to the abdominal ganglion; (2) the isolated head, still connected to the abdominal ganglion by the pleuroabdominal connectives, was set up as described previously (Koch et al., 1984). The latter preparation responds to food stimuli (scawced) with biting movements, cxhibiting the basic features of food arousal. In each experiment, the abdominal ganglion was desheathed by cutting away the connective tissue with fine scissors. Single- or double-barreled microelectrodes filled with $2 \mathrm{M}$ potassium acetate or $3 \mathrm{M} \mathrm{KCl}$ were used to record membrane potential and to pass current into neurons. The ASW in the recording chamber was maintained at a constant temperature $\left( \pm 1^{\circ} \mathrm{C}\right)$ by a Peltier cooling plate. The range of bath temperatures between experiments was $15-19^{\circ} \mathrm{C}$. All data were tape-recorded and played back on a Brush 440 chart recorder (full scale cut-off frequency $40 \mathrm{~Hz}$ ) or a storage oscilloscope for photographing. Two methods were used to test for monosynapticity of connections: (1) $60 \mu \mathrm{M}$ tetrodotoxin (TTX; Calbiochem) was used to block voltagegated sodium channels, thereby blocking or raising the thresholds for action potentials in most cells in the ganglion; (2) a high divalent cation solution was used in some experiments to raise spike threshold, thereby blocking most polysynaptic pathways. This solution, which contained $165 \mathrm{mM} \mathrm{Mg}^{2+}(3 \times$ normal $)$ and $30 \mathrm{mM} \mathrm{Ca}^{2+}(3 \times$ normal $)$, was prepared by mixing isotonic $\mathrm{CaCl}_{2}$ and isotonic $\mathrm{MgCl}_{2}$ with $\mathrm{ASW}$. To check for monosynapticity of the connections from cells in the abdominal ganglion to cells in the branchial ganglion, the abdominal ganglion was placed in a small well filled with saline in which $\mathrm{Ca}^{2+}$ was replaced with $\mathrm{Co}^{2+}: \mathrm{NaCl}, 460 \mathrm{~mm} ; \mathrm{MgCl}_{2}, 55 \mathrm{~mm} ; \mathrm{CoCl}_{2}, 10 \mathrm{~mm} ; \mathrm{KCl}, 10 \mathrm{~mm}$; HEPES buffer ( $\mathrm{pH} 7.6$ ), $10 \mathrm{~mm}$. Putative transmitters were applied to the ganglion either by mixing a small volume of concentrated solution with the bath, or, in experiments in which the ganglion was continuously superfused, by injecting a concentrated bolus of drug into the superfusion line.

Morphology. Lucifer yellow CH ( $5 \%$ aqueous solution; Sigma) or 5,6carboxyfluoresccin (Kodak) (Rao ct al., 1986) was injected by iontophoresis (5-10 $\mathrm{nA}$ for 30-60 min) into the somata of neurons to determine the distribution of neuronal processes. After allowing the dye to diffuse throughout the cell, the ganglion was fixed for $2 \mathrm{hr}$ in a solution of $0.1 \mathrm{~m}$ phosphate buffer containing $4 \%$ paraformaldehyde plus $30 \%$ sucrose. The tissue was cleared by soaking it in a solution of glycerol mixed $6 / 1$ with phosphate buffer and viewed in whole amount with a Leitz microscope equipped for epifluorescence viewing.

For immunostaining, we used a modified version of the technique developed by Longley and Longley (1986). The abdominal ganglion from a 70-100 gm animal was desheathed, and one or both of the R20 cells was identified electrophysiologically and filled iontophoretically with Lucifer yellow for later identification. The ganglion was then treated in the following sequence: fixation for 5-6 hr in 4\% paraformaldehyde solution containing $0.1 \mathrm{M}$ phosphate buffer $(\mathrm{PB}), \mathrm{pH} 7.4$, and $24 \%$ sucrose at $4^{\circ} \mathrm{C}$; washing ( 3 times per $24 \mathrm{hr}$, each time with $3-5$ washes) with phosphate buffer containing $2 \%$ Triton X-100 (PB/TX) at $4^{\circ} \mathrm{C}$; incubation for $3 \mathrm{hr}$ at room temperature in normal goat serum (NGS) in PB/TX (1:130) to reduce nonspecific binding; exposure overnight at $4^{\circ} \mathrm{C}$ to $\mathrm{PB} / \mathrm{TX} / \mathrm{NGS}$ containing rabbit anti-serum either to $\mathrm{SCP}_{\mathrm{B}}$ or to FMRFamide (1:100 dilution); washing with $\mathrm{PB} / \mathrm{TX}$ followed by incubation in goat anti-rabbit IgG rhodamine-conjugated antibody in PB/ TX $(1: 50)$ at $4^{\circ} \mathrm{C}$; washing with $\mathrm{PB}$; clearing with glycerol plus $\mathrm{PB}(6 / 1)$; and mounting on slides for viewing with epifluorescence with filter packs for viewing either Lucifer yellow or rhodamine. Polyclonal antibodies to FMRFamide were obtained from Peninsula Laboratories, and polyclonal antibodies to $\mathrm{SCP}_{\mathrm{B}}$ were obtained from R. Scheller (see Mahon et al., 1985).

Pharmacology. Various neurotransmitters were applied to neurons, either by injecting a concentrated solution into the bath near the ganglion from a $50 \mu$ l pipette, by puffing a small amount of concentrated drug solution from a micropipette with its tip closely apposed to the cell membrane, or by superfusing the ganglion with large volumes of the drug-containing solution. In some cases, the polysynaptic effects of applied transmitters were minimized by raising the thresholds of polysynaptic pathways by bathing the ganglion either in high divalent cation solution (above) or in ASW containing $60 \mu \mathrm{M}$ TTX (Calbiochem).

Acetylcholine was obtained from Sigma. Five neuropeptides that are known to be present in the Aplysia nervous system were used in various experiments: FMRFamide (Lehman et al., 1984) and small cardioactive peptides $A$ and $B\left(\mathrm{SCP}_{\mathrm{A}}\right.$ and $\left.\mathrm{SCP}_{\mathrm{B}}\right)$ (Morris et al., 1982; Cropper et al., 1987a; Lloyd et al., 1987) were purchased from Peninsula Laboratories. Synthetic buccalin (Cropper et al., 1988) was obtained from the Howard Hughes Medical Institute Protein Center Core Facility at Columbia University. Synthetic myomodulin (Cropper et al., 1987b) was obtained from Applied Biosystems.

Biochemistry. All of the neuropeptides that have been isolated to date in Aplysia, except the alpha bag cell peptide (Rothman et al., 1983), contain methionine. Therefore, we chose ${ }^{35} \mathrm{~S}$ methionine to radiolabel peptides contained in the R20 cells. R 20 neurons were physiologically identified in desheathed abdominal ganglia and were marked by iontophoresis of Fast green dye (Sigma). Abdominal ganglia were then incubated with $0.5 \mathrm{mCi}$ of ${ }^{35} \mathrm{~S}$ methionine (Amersham) for $30 \mathrm{hr}$ at $18^{\circ} \mathrm{C}$ in $1 \mathrm{ml}$ of $50 \%$ ASW $/ 50 \%$ sterile hemolymph $(0.2 \mu \mathrm{m}$ filtered) supplemented with penicillin $(10,000 \mathrm{U} / \mathrm{ml})$, streptomycin $(10 \mathrm{mg} / \mathrm{ml})$, and colchicine (2.5 $\mu \mathrm{l}$ of $1 \mathrm{~m}$ colchicine dissolved in DMSO). Colchicine was added to inhibit axonal transport, in order to raise intrasomatic peptide levels and reduce the levels of radiolabeled peptides that might be present in fibers and terminals near the somata of dissected neurons (Lloyd et al., 1985). After the incubation period, ganglia were rinsed with $20 \mathrm{ml}$ of filtered ASW and then maintained for a $6 \mathrm{hr}$ chase period in a solution of ASW containing the antibiotics and colchicine in the same concentration as described above. At the end of the chase period, ASW was replaced with several washes of a solution of $50 \%$ propylene glycol $/ 50 \%$ ASW, and the ganglia were placed in a freezer at $-20^{\circ} \mathrm{C}$ to allow a slow substitution with propylene glycol. Individual R20 neurons were manually dissected and transferred to a glass microtube containing $100 \mu 1$ of $0.1 \mathrm{M}$ acetic acid and $3 \mathrm{nmol} \mathrm{SCP}, 3 \mathrm{nM} \mathrm{SCP}_{\mathrm{B}}$, and $6 \mathrm{nM}$ FMRFamide. The microtubes then were heated to $95^{\circ} \mathrm{C}$ for $5 \mathrm{~min}$. The extract was filtered and subjected to reverse-phase, high-performance liquid chromatography (RP-HPLC).

The identity of the peptides synthesized by the R 20 cells was established using a 3-stage sequence of RP-HPLC with 3 different counterions [trifluoroacetic acid (TFA), heptafluorobutyric acid (HFBA), and triethylamine (TEA)] that previously had been shown to be effective in scparating $\mathrm{SCP}_{\mathrm{A}}, \mathrm{SCP}_{\mathrm{B}}$, and myomodulin (Cropper ct al., 1987b). All 3 stages of chromatography were carried out on a DuPont Liquid Chromatograph system 850 using an Aquapore RP300 column $(4.6 \times 220$ $\mathrm{mm}$ ) with a flow rate of $1 \mathrm{ml} / \mathrm{min}$.

In the first stage of chromatography, the column was eluted for 10 min with a gradient ranging from 5 to $15 \%$ of solvent $B$, followed by a 20 min elution with a gradient from 15 to $20 \%$ solvent B, and ending with a 30 min elution from $20-25 \%$ solvent $B$. Solvent $A$ was $0.01 \mathrm{M}$ TFA in $\mathrm{H}_{2} \mathrm{O}$. Solvent B was $0.01 \mathrm{M}$ TFA in $\mathrm{CH}_{3} \mathrm{CN}$.

In the second stage of chromatography, the column was eluted in 42 min with a linear gradient from 15 to $36 \%$ solvent $B$. Solvent $A$ was $0.01 \mathrm{M}$ HFBA in $\mathrm{H}_{2} \mathrm{O}$. Solvent B was $0.01 \mathrm{M}$ HFBA in $\mathrm{CH}_{3} \mathrm{CN}$.

In the third stage of chromatography, the column was eluted with a linear gradient from 20 to $50 \%$ solvent $\mathrm{B}$ in $35 \mathrm{~min}$. The composition of solvent $A$ was $0.01 \mathrm{~m}$ TEA acetate ( $\mathrm{pH}$ 5.5) in $\mathrm{H}_{2} \mathrm{O}$. The composition of solvent $B$ was $0.01 \mathrm{M}$ TEA acetate (pH 5.5) in $20 \% \mathrm{H}_{2} \mathrm{O} / 80 \% \mathrm{CH}_{3} \mathrm{CN}$.

Elution of synthetic peptides was monitored at $215 \mathrm{~nm}$ using an ISCO $\mathrm{V}^{4}$ absorbance detector, while ${ }^{35} \mathrm{~S}$-radiolabeled native peptides were detected by scintillation counting aliquots of fractions. 

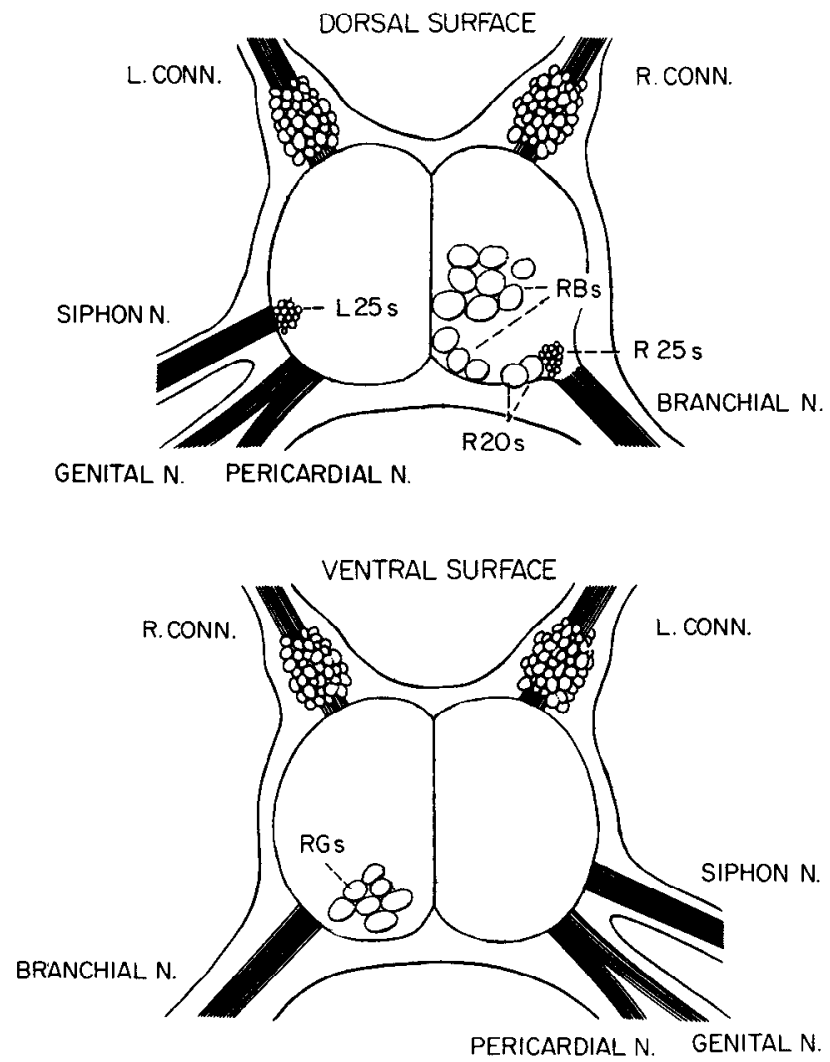

Figure 1. Relative locations of the R20 cells and the cells to which they connect in the abdominal ganglion. Because the R20 cells are near the edge of the ganglion, they can be impaled from either the dorsal or the ventral side of the ganglion, depending on how the branchial nerve is twisted during pinning. Other cells on this map are described in more detail by Brown et al. (1985), Koester and Kandel (1977), Byrne (1983), and Koester (1983).

Patterns of labeling of individual R20 neurons dissected from the same ganglion were compared by chromatographing single radiolabeled cells using a single-stage chromatographic procedure that was identical to the one used in the first step of chromatography that was employed for pooled neurons.

\section{Results}

Characterization of the $R 20$ cells

A pair of electrically coupled neurons, which we have named the R20 cells, were found to influence the frequency of bursting of the R25/L25 network. These cells can be identified by the following criteria. (1) They are located at the right dorsal-caudal edge of the abdominal ganglion, just medial to the origin of the branchial nerve (Fig. 1). (2) Their cell bodies, which typically are pale gray in color and occasionally contain dark green pigment bodies at their base, are about $100-150 \mu \mathrm{m}$ in diameter. (3) They are normally silent, with no obvious background synaptic input and are not excited by tactile or noxious stimuli to the mantle organs or by food stimuli presented to the lips. (4) They are electrically coupled to each other (Fig. $2 A$ ), with a mean DC coupling ratio between cell bodies of $0.18 \pm 0.06$ (mean \pm SEM; $n=5$ ). (5) When fired repetitively they exhibit pronounced spike broadening and a prolonged depolarizing after-potential (Fig. 2, B, C). (6) They are excited by application of $\mathrm{SCP}_{\mathrm{A}}$ and by $\mathrm{SCP}_{\mathrm{B}}$ (Fig. $2 D$ ) and are inhibited by application of acetylcholine, myomodulin, buccalin, and FMRFamide (data not shown). (7) They make slow inhibitory connections to the cells in the RB and RG clusters in the abdominal ganglion and to the cells in the branchial ganglion (Fig. 3). (8) They trigger respiratory pumping by increasing the frequency of bursting of the R25/L25 network (Fig. 4). (9) They receive only weak synaptic input (usually inhibition) from stimulation of the pleuroabdominal connectives and peripheral nerves of the abdominal ganglion, and very weak inhibitory synaptic input from cell L10 (data not shown). (10) They send axons out of the branchial, siphon, genital, and pericardial nerves.

\section{Characterization of synaptic actions of the $R 20$ cells}

We found that the R20 cells inhibit the cells of the RB cluster (Fig. 3, $A, D$ ), a previously characterized (Frazier et al., 1967; Eisenstadt et al., 1973) group of 10-15 neurons located just medial to the $\mathrm{R} 20$ cells (Fig. 1). One of the $R B$ cells, $R B_{H E}$, is a unique individual that is an excitatory modulator of the heart (Mayeri et al., 1974). In 33 of 33 pairs tested, in 23 preparations, R20 cells were found to produce strong inhibition of randomly selected RB cells. As many as $7 \mathrm{RB}$ cells were shown to be inhibited by an $\mathrm{R} 20$ cell in a single preparation. These data strongly suggest that all of the RB cells are inhibited by both of the $\mathrm{R} 20$ cells.

We found that the $\mathrm{R} 20$ cells also inhibit neurons in a previously unidentified cluster that we have named the RG cells (Fig. $3 B$ ). The somas of the RG cells, which range in size from 100 to $150 \mu \mathrm{m}$, are located on the right caudoventral surface of the abdominal ganglion (Fig. 1). They appear white when viewed with epi-illumination, suggesting that they may be neurosecretory cells (Frazier et al., 1967). Brown et al. (1985) found that neurons in this area are stained by an antibody to FMRFamide. After identifying the RG cells electrophysiologically, we marked them by iontophoresis of Lucifer yellow and then stained the ganglion with fluorescent-labeled antibody to FMRFamide. The Lucifer-labeled cells were stained by the antibody (unpublished observations), suggesting that the RG cells are the same cluster described by Brown et al. (1985). The RG cells are characterized electrophysiologically by a slow, spontaneous beating firing pattern, excitation by myomodulin and SCP, and a depolarization/ hyperpolarization response to application of FMRFamide. Firing cell L10 (Frazier et al., 1967) produces a weak conjoint synaptic response in these cells: fast excitation followed by slow inhibition. A burst in the R25/L25 network produces a similar effect: weak excitation followed by slow inhibition. For 20 out of 20 RG cells tested in 10 preparations, firing an R20 cell produced synaptic inhibition (Fig. $3 B$ ). These results suggest that all of the RG cells are inhibited by both of the R20 cells.

We found that the R20 cells also inhibit cells in the branchial ganglion. This ganglion, which is located in the efferent vein of the gill, had been shown previously to consist primarily of excitatory gill motoneurons, which we refer to here as the BRG cells (Kurokawa and Kuwasawa, 1985, 1988). These cells are known to be excited by the cells of the R25/L25 network (Koester, 1983). Therefore, firing an R20 cell elicits not only a short latency, direct inhibitory action on the BRG cells, it also triggers, with some delay, an excitatory synaptic input from the R25/ L25 network (Fig. 3C). Of 19 R20/BRG pairs tested in 7 preparations, the $R 20$ cell produced inhibition of the BRG cell in every case. Thus many, and perhaps all, of the BRG cells are inhibited by the R20 cells. The R 20 cells send axons out the 
A
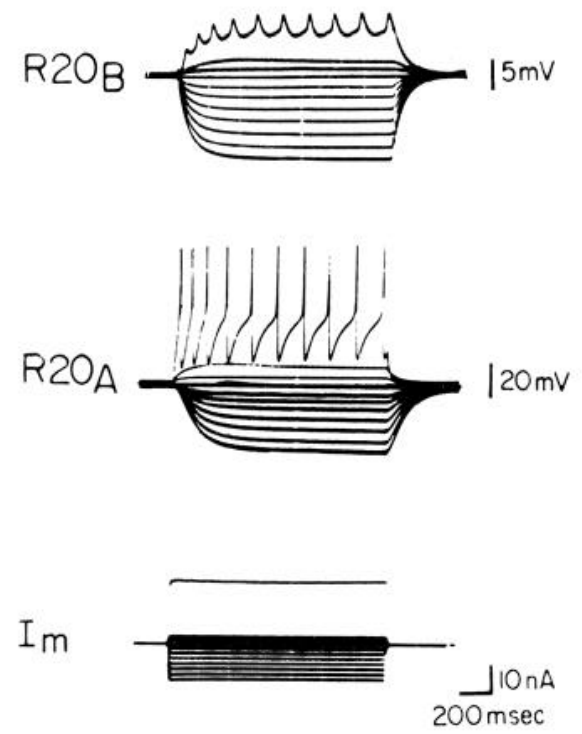

B

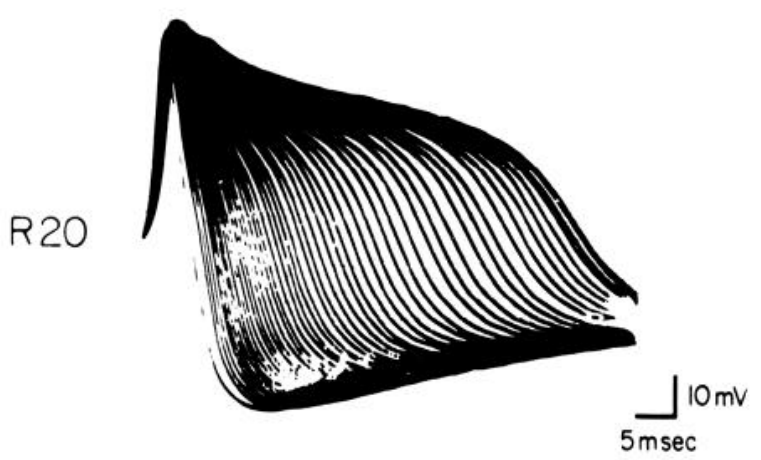

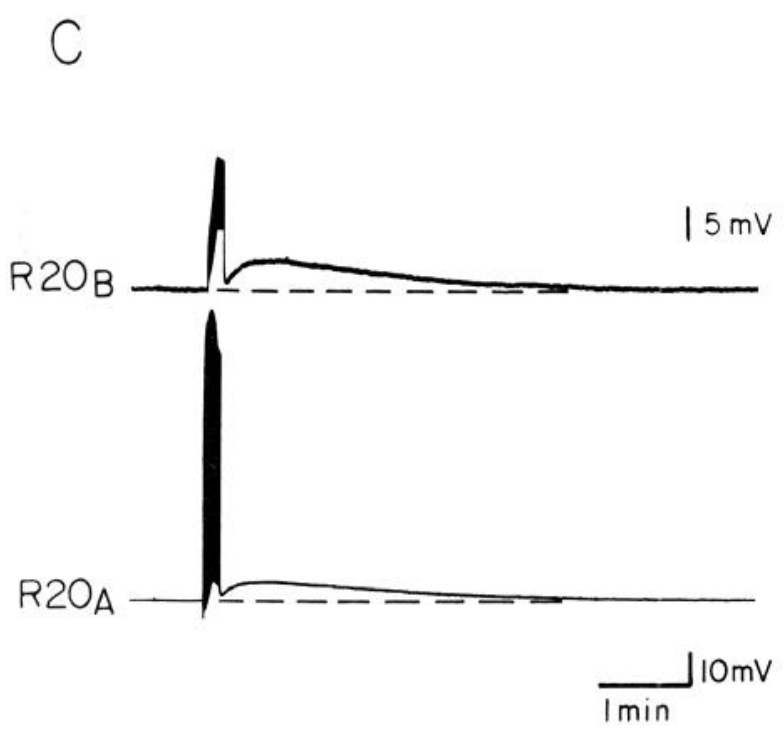

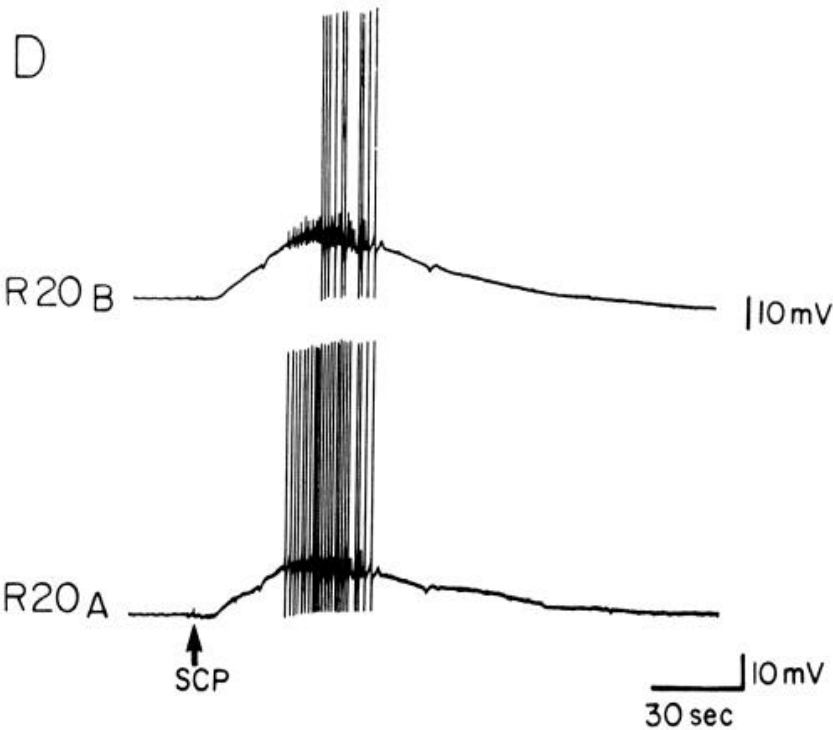

Figure 2. Electrophysiological criteria for identifying the $2 \mathrm{R} 20$ cells. $A$, Injecting current into R $20_{\mathrm{A}}$ demonstrates that the $2 \mathrm{R} 20$ cells are electrically coupled. $B$, Pronounced spike-broadening occurs during a $10 \mathrm{sec}$ train of spikes elicited by brief current pulses injected at $5 \mathrm{~Hz}$ into the soma of one R20 cell. $C$, Firing one R20 cell (bottom) by current injection elicits electrotonic synaptic potentials in the other R20 cell, plus long depolarizing afterpotentials that occur in both cells. DC coupling ratio between these 2 cells was 0.23 . D. Bath application of $50 \mu \mathrm{l}$ of $10 \mu \mathrm{M}$ SCP $\mathrm{B}_{\mathrm{B}}$ excites the $\mathrm{R} 20$ cells (bath volume $2 \mathrm{ml}$ ). $\mathrm{SCP}_{\mathrm{A}}$ has a similar effect and is equipotent (data not shown).

genital nerve, but in preliminary experiments we found no sign of connections to the cells in the genital ganglion.

We tested whether the R20 connections to the RB, RG, and BRG cells are monosynaptic by reducing the effectiveness of polysynaptic transmission. For the RB and the RG cells, the abdominal ganglion was bathed in a saline in which $\mathrm{Ca}^{2+}$ and $\mathrm{Mg}^{2+}$ were elevated 3-fold above their normal levels, in order to raise action potential threshold. In both cases, the inhibitory connections to these cells from the R20 cells were unaffected (Fig. 3, $A, B$ ). For examining the $\mathrm{R} 20$ to branchial ganglion cell connections, chemical transmission in the abdominal ganglion was blocked in some experiments by placing the ganglion in a
$1 \mathrm{cc}$ well filled with $\mathrm{Ca}^{2+}$-free saline containing $10 \mathrm{mM} \mathrm{Co}^{2+}$. In other cases, $3 \times \mathrm{Ca} / \mathrm{Mg}$ saline was used to reduce all polysynaptic transmission. In every case, the inhibitory connections made to the BRG neurons by the R 20 cells were unaffected by manipulations that should reduce or block most polysynaptic signaling (data not shown).

We have not systematically tested whether the 2 R 20 cells have the same strength of synaptic connection onto all of their followers. However, in the few cases where we have looked, the 2 cells appear to be roughly equipotent in their synaptic actions. An example is shown in Figure $3 D$, in which the inhibitory actions of the 2 R 20 cells on an RB cell are compared. The 


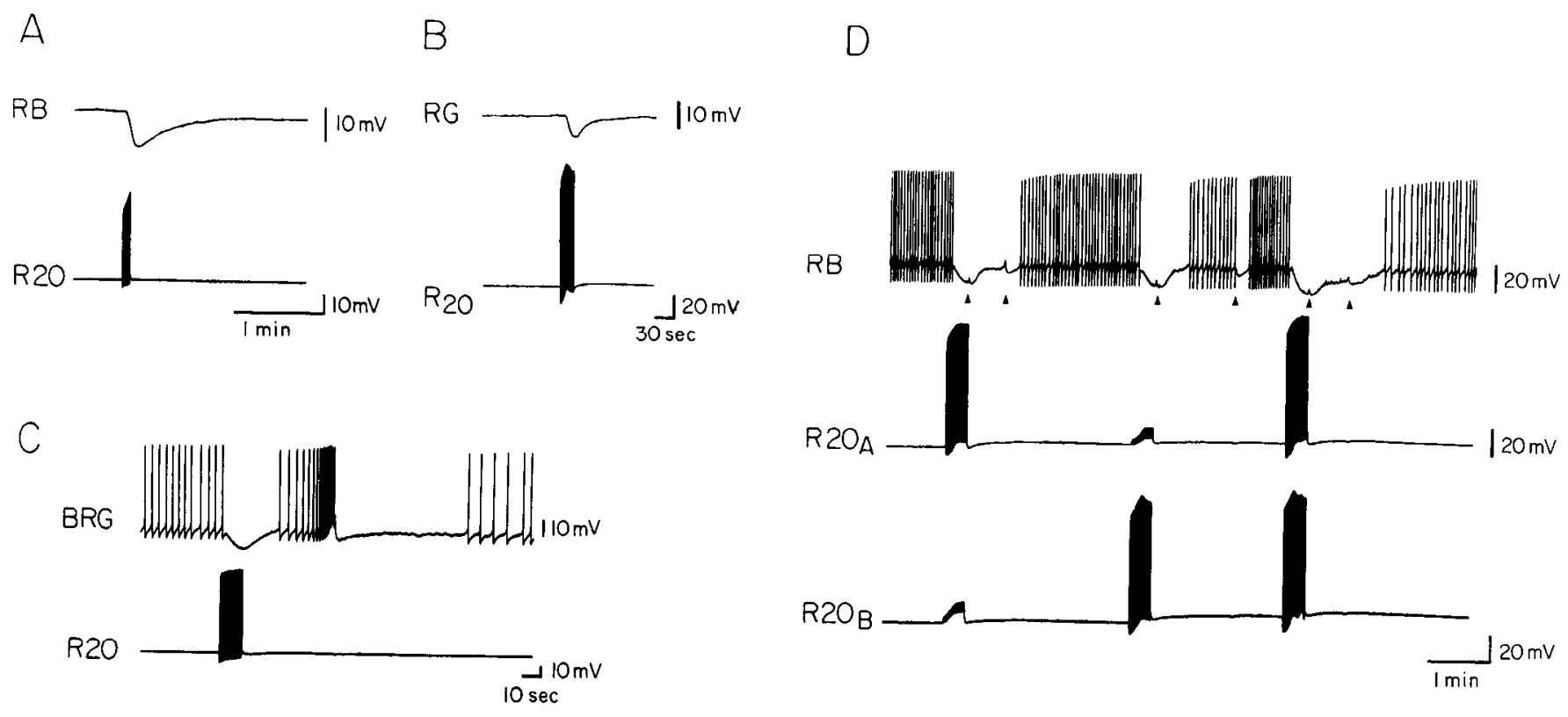

Figure 3. Synaptic actions of the R20 cells. A, Firing a brief burst of spikes in an R20 cell at $5 \mathrm{~Hz}$ for 5 sec elicits a short-latency, long-lasting inhibition of an RB cell with the ganglion bathed in high divalent cation solution to reduce polysynaptic activity. $B$, Firing a brief burst of spikes in an R20 cell at $10 \mathrm{~Hz}$ elicits a short-latency, long-lasting inhibition of an RG cell with the ganglion bathed in high divalent cation solution to reduce polysynaptic activity. C, Firing a brief burst of spikes in an R20 cell at $5 \mathrm{~Hz}$ for 6 sec elicits a short-latency, long-lasting inhibition of a branchial ganglion (BRG) neuron. The inhibition is followed about $30 \mathrm{sec}$ later by a strong synaptic excitation produced by a burst in the R25/ L25 network. $D$, The inhibitory synaptic actions produced by the 2 R 20 cells on a common RB follower cell are approximately equal, and partially additive. Arrows mark the conjoint excitatory/inhibitory synaptic events produced in RB by bursts in the R25/L25 network. The R20 cells were fired at $10 \mathrm{~Hz}$ in each instance.

inhibition produced by firing either cell alone is approximately the same. In addition, the short-latency inhibition in each case is followed by a pair of conjoint excitatory-inhibitory PSPs (arrowheads) that are generated by activity in the R25/L25 network (Byrne, 1983; Koester, 1983). Firing the 2 R20 cells in synchrony produces a slightly additive effect on the short-latency hyperpolarization of the RB cell. This effect may be underestimated if the IPSP is close to its equilibrium potential. This paired burst in the R20 cells also elicits a pair of bursts in the R25/L25 network, monitored by the E/I responses in the RB cell.

Firing either of the R20 cells by current injection can trigger an isolated episode of respiratory pumping or increase the frequency of its spontaneous occurrence. Because of the extensive coupling between cells in the R25/L25 network, all cells in the network fire in a synchronous burst during each episode of respiratory pumping (Byrne, 1983; Koester, 1983). Therefore, it is possible to monitor the activity of this entire population of cells by recording from a single individual. Figure $4 A 1$ shows that firing a brief burst of spikes in R20 elicits 2 bursts in the R25/ L25 network.

The response of the $\mathrm{R} 25 / \mathrm{L} 25$ network to activity in the R20 cells has an exceptionally wide dynamic range. The $\mathrm{R} 20$ cell was fircd at $5 \mathrm{~Hz}$ in the experiment illustrated in Figure $4 A$. Figure $4 B$ demonstrates the effect of firing R 20 cells in another preparation for $10 \mathrm{~min}$ at $1 \mathrm{~Hz}$. The threshold frequency of R20 firing required to modulate the R25/L25 network is exceptionally low. In 4 preparations, a $30 \mathrm{~min}$ train of action potentials in a single $\mathrm{R} 20$ cell at $0.1 \mathrm{~Hz}$ elevated the frequency of respiratory pumping by an average of $60 \%$. This effect was found to be statistically significant using a 1 -sided $t$ test $(p<0.05)$. In other experiments, firing R20 at $10 \mathrm{~Hz}$ for several seconds was found to produce up to a 100 -fold increase in the rate of respiratory pumping.

Two types of experiment in which polysynaptic activity in the ganglion was reduced suggest that the connection to the R25/ L25 network is monosynaptic. (1) The excitatory effect on the $\mathrm{R} 25 / \mathrm{L} 25$ network persists when the R20 cells are fired with the ganglion bathed in high divalent cation solution (Fig. 4A2). (2) It has becn shown previously that the spontaneous bursts in the R25/L25 network are mediated by TTX-resistant plateau potentials (Koester and Koch, 1987). With the ganglion bathed in TTX, firing the R20 cells elicits calcium-mediated action potentials that, although reduced in amplitude, can still elicit postsynaptic responses. These action potentials increase the amplitude, duration, and frequency of the plateau potentials in the L25 and R25 cells that underlie the network bursts (Fig. 5A).

\section{Characterization of the transmitter type of the $R 20$ cells}

The $\mathrm{R} 20$ cells have many characteristics often associated with peptidergic neurons in Aplysia: sparse synaptic input, little or no pigmentation, pronounced spike broadening, and long-lasting postsynaptic effects on their follower cells. In order to determine whether R20 neurons contain known Aplysia neuropeptides, we labeled these cells with ${ }^{35} \mathrm{~S}$-methionine and subjected their extract to sequential chromatography in the presence of synthetic neuropeptides. Pilot experiments in which a single mode of chromatography was used indicated that the R20 neurons may contain 3 neuropeptides previously found in Aplysia neurons: FMRFamide (Lehman et al., 1984), $\mathrm{SCP}_{\mathrm{A}}$, and $\mathrm{SCP}_{\mathrm{B}}$ (Morris et al., 1982; Lloyd et al., 1987). To establish unequivocally whether these peptides are present in R20 cells, 2 experiments were performed using pooled ${ }^{35} \mathrm{~S}$-methionine-labeled neurons. In the first experiment, 4 R 20 cells dissected from 3 
A1
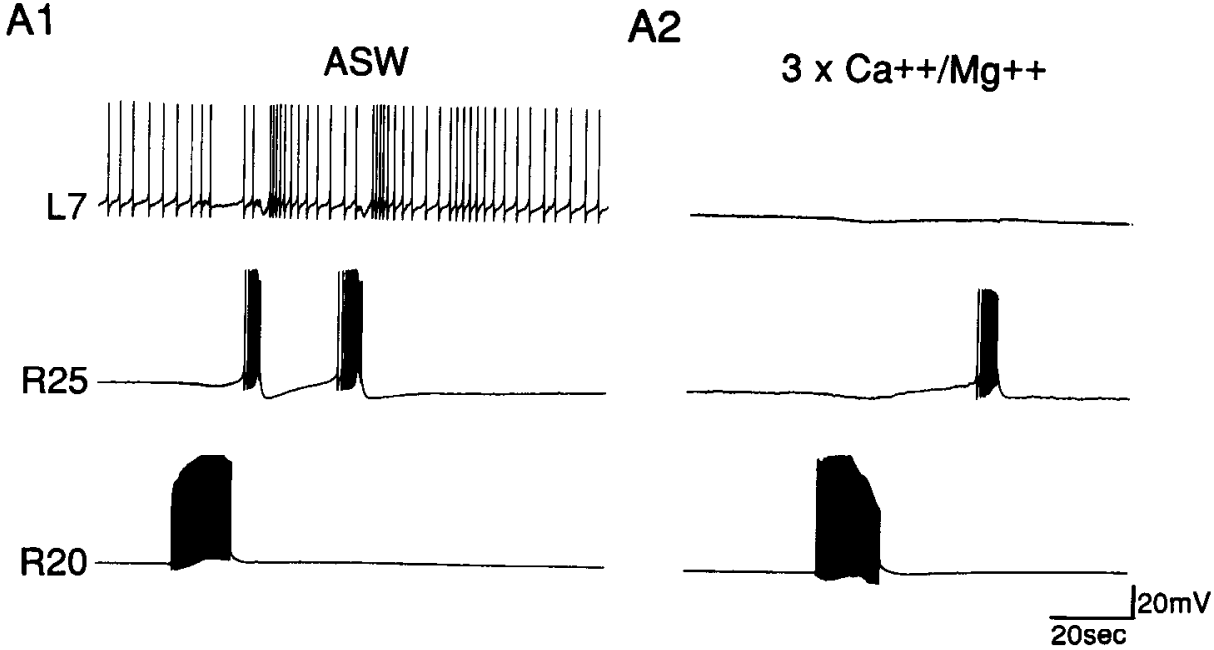

B

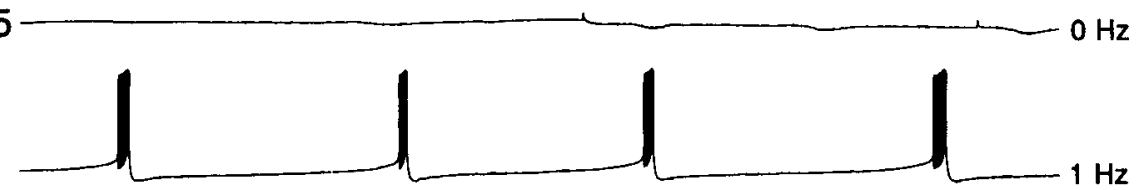

STIMULATE R20

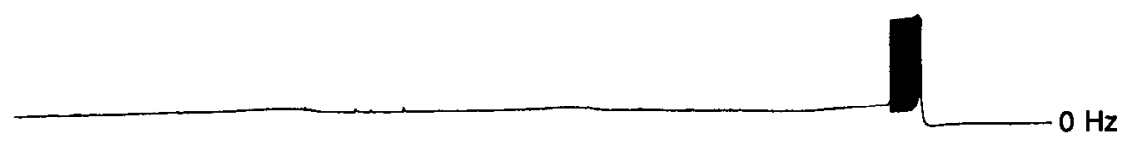

$1 \mathrm{~min} 20 \mathrm{mV}$

Figure 4. The R20 cells excite cells of the R25/L25 network. A1, Firing a short burst of spikes in R20 by injecting brief depolarizing current pulses at $5 \mathrm{~Hz}$ elicits a pair of respiratory pumping episodes, monitored by the inhibition/excitation (I/E) responses in gill motoneuron L7 and by the excitation of an R25 cell. The initial inhibition recorded in the R25 cell in this example was not observed in most preparations. $A 2$, With the ganglion bathed in $3 \times$ $\mathrm{Ca}^{2+}-3 \times \mathrm{Mg}^{2+} \mathrm{ASW}$, only a very weak burst is triggered in the R25 cell (peak firing frequency $6.6 \mathrm{~Hz}$ c.f. $25 \mathrm{~Hz}$ in A1). The rest of the R25/L25 network presumably was also excited only weakly, if at all, as L7 did not show its characteristic $\mathrm{I} / \mathrm{E}$ input. This lack of an effect on L7 is consistent with the observation that each L 25 or R25 cell connects to only a small subset of the entire population of motoneurons that drive respiratory pumping. $B$, Moderate frequency, tonic firing of $\mathrm{R} 20$ by current injection can initiate repetitive respiratory pumping activity in a ganglion in which there was initially no spontaneous activity. A $30 \mathrm{~min}$, consecutive trace of $R 25$ activity is shown. The R20 cell was silent during the first and third traces; during the middle trace it was fired at $1 \mathrm{~Hz}$ by injecting brief current pulses. abdominal ganglia were used and in the second experiment, 5 R20 cclls dissceted from 4 abdominal ganglia were used. The 2 experiments gave virtually identical results. Figures 6 and 7 show the results obtained with 5 radiolabeled neurons. Figure $6 A$ shows results obtained when the R20 extract was chromatographed together with synthetic $\mathrm{SCP}_{\mathrm{A}}, \mathrm{SCP}_{\mathrm{B}}$, and FMRF-amide in the presence of TFA. When TFA is used as a counterion, peptides elute largely on the basis of their hydrophobicity. In addition to the early eluting radioactivity which presumably contains free methionine, we also observed several other distinct peaks of radioactivity (Fig. 6A). On the basis of the elution characteristics of these peaks, we assume that they represent methionine-containing peptides. Three of these radiolabeled peaks coeluted with synthetic peptides that were detected by absorbance measurements. The first of these peaks coeluted together with the synthetic FMRFamide and the latter 2 coeluted with $\mathrm{SCP}_{\mathrm{A}}$ and $\mathrm{SCP}_{\mathrm{B}}$, respectively.

Each of the radiolabeled peaks coeluting with synthetic peptides was subjected to a second stage of chromatography that was performed in the presence of HFBA. This counterion pairs with basic residues and therefore preferentially increases the retention time of peptides containing basic residues. When the radiolabeled peak that contained synthetic FMRFamide was subjected to this mode of chromatography (Fig. $6 B$ ), the retention time of radiolabeled material and synthetic FMRFamide became different; i.e., the 2 no longer coeluted. This separation indicates that the R20 neurons do not synthesize significant amounts of FMRFamide. Unlike the result for the FMRFamide peak, when the $\mathrm{SCP}_{\mathrm{A}}$ and $\mathrm{SCP}_{\mathrm{B}}$ peaks from the first HPLC run (Fig. $6 \mathrm{~A}$ ) were chromatographed in the presence of HFBA, the radioactive peaks and absorbance peaks continued to coelute (Fig. 7, $A, C$ ).

The radioactive peaks containing synthetic $\mathrm{SCP}_{\mathrm{A}}$ and $\mathrm{SCP}_{\mathrm{B}}$ in the second HPLC run (Fig. 7, $A, C$ ) were subjected to a third stage of chromatography in the presence of TEA. TEA is a hydrophobic acidic ion-pairing reagent; i.e., it preferentially delays the elution time of peptides that contain acidic residues. In the presence of TEA, synthetic $\mathrm{SCP}_{\mathrm{A}}$ and $\mathrm{SCP}_{\mathrm{B}}$ continued to coelute with radioactivity (Fig. $7, B, D$ ). Because the radioactive peaks coeluted with synthetic $\mathrm{SCP}_{\mathrm{A}}$ and $\mathrm{SCP}_{\mathrm{B}}$ in 3 different modes of chromatography, we conclude that the R20 neurons contain both $\mathrm{SCP}_{\mathrm{A}}$ and $\mathrm{SCP}_{\mathrm{B}}$.

The physiological actions of the 2 R20 neurons suggest that they have similar functions (Fig. $3 D$ ). In order to investigate whether they are identical in terms of the neuropeptides they synthesize, we compared the profiles of synthesis of the radiolabeled peptides in 2 pairs of R20 neurons dissected from 2 ganglia. Figure 8 shows the results from one such experiment. Both of the R20 neurons from a single ganglion contained both of the SCPs and displayed the same radioactive peaks. The other R20 pair gave similar results. We thus conclude that both R20 cells synthesize the same ${ }^{35} \mathrm{~S}$-methionine-labeled peptides. 

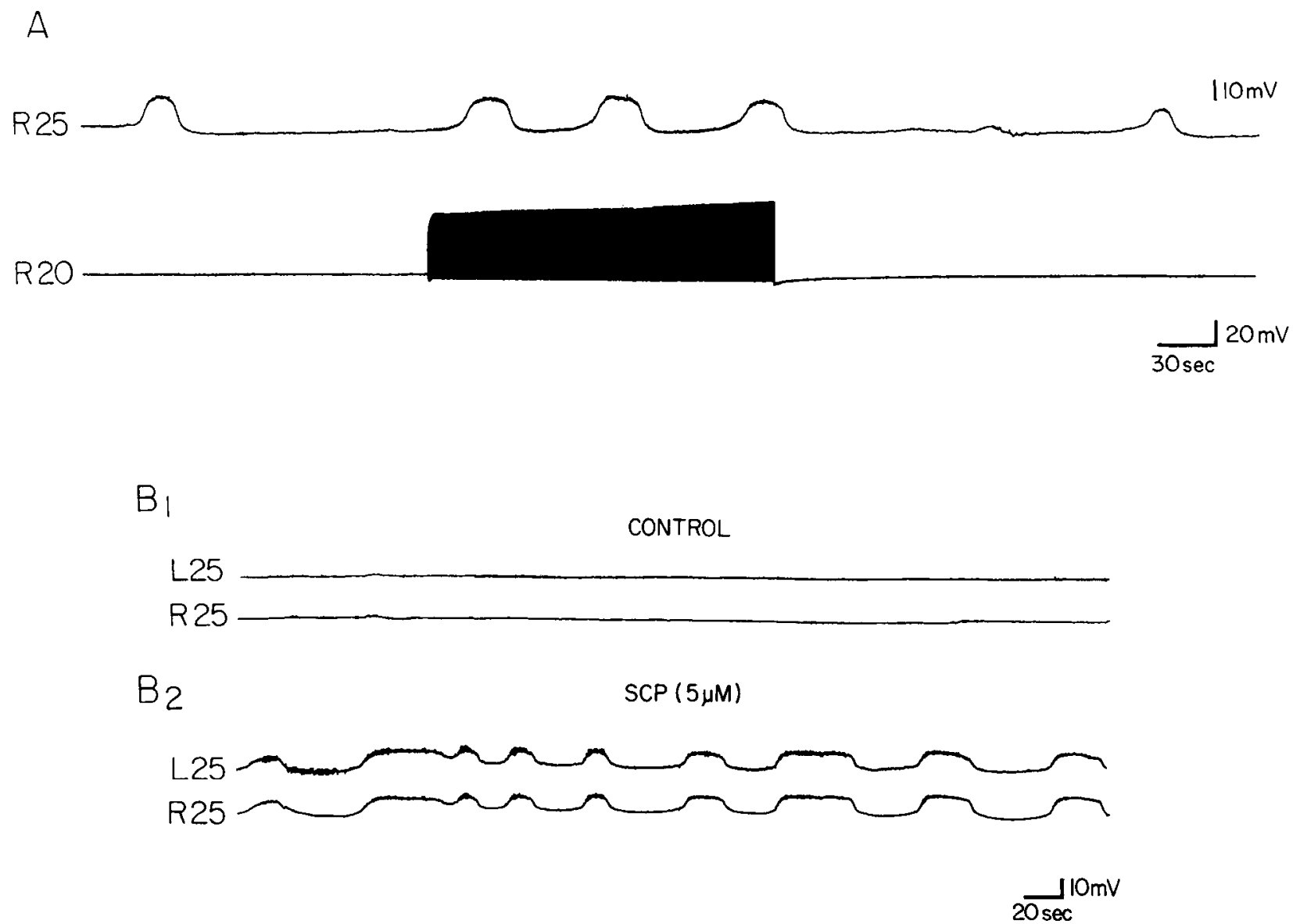

Figure 5. SCP mimics the effects of the R20 cells on the plateau potentials generated in the R25 and L25 cells in the presence of TTX. $A$, Firing an R20 cell at $10 \mathrm{~Hz}$ for 2.5 min triggered 3 plateau potentials in the R25/L25 network, as monitored in a single R25 cell. The ganglion was bathed in ASW containing $60 \mu \mathrm{M}$ TTX throughout. $B$, SCP elicited significant plateau potential activity in the R25/L25 network. Simultaneous recording from an R25 and an L25 cell. TTX, $60 \mu \mathrm{M}$, was present throughout. There was no spontaneous plateau activity until a bolus of SCP B $_{\mathrm{B}}$ was added to the bath near the end of the first 2 traces. It rapidly initiated repetitive plateau activity throughout the R25/L25 population, as monitored in 2 of the 30 cells in the network.

Independent confirmation of the biochemical evidence that the R20 cells contain SCP was obtained using fluorescein-labeled antibodies to stain the abdominal ganglion for $\mathrm{SCP}_{\mathrm{B}}$-immunoreactive neurons. Before staining, the ganglion was desheathed and either one or both of the R20 cells was identified electrophysiologically and labeled by iontophoresis with Lucifer yellow. In 3 preparations, only 1 of the 2 R20 cells could be found and filled with Lucifer yellow. Presumably the other R20 cell was damaged during desheathing. For each of these 3 ganglia the Lucifer-labeled R20 cell was the only neuron in the right lower quadrant of the ganglion to stain positively for the $\mathrm{SCP}_{\mathrm{B}}$ antibody. In a fourth ganglion, both $\mathrm{R} 20$ cells were identified and filled. In that specimen, the 2 Lucifer-filled R20 cells plus 1 adjacent cell bound the antibody (Fig. 9). We also consistently observed a pair of small $\mathrm{SCP}_{\mathrm{B}}$-immunoreactive cells on the left side of the ganglion as described by Lloyd et al. (1985) in juvenile Aplysia. Lloyd et al. (1985) only occasionally observed an SCPimmunoreactive cell in the region of the ganglion where we found the R20 cells in adult animals. The inconsistency of their observations may reflect access problems arising from the fact that they did not desheath the juvenile ganglia used in their experiments. Neither the cells on the left nor the right side of the ganglion were stained when they used sectioned material from adult ganglia. We have no ready explanation for this difference in results.

Peptides $\mathrm{SCP}_{\mathrm{A}}$ and $\mathrm{SCP}_{\mathrm{B}}$, which are widely distributed in the Aplysia nervous system (Mahon et al., 1985; Cropper et al., $1987 \mathrm{a}$ ), had been shown to exert a number of modulatory actions on nerve and muscle cells (Abrams et al., 1984; Lloyd et al., 1984, 1985, 1988; Richmond et al., 1986; Lukowiak and Colmers, 1987; Sossin et al., 1987). We found that both of the SCPs mimicked the effects of the R20 cells on the R25/L25 network: bath application of $\mathrm{SCP}_{\mathrm{A}}$ or $\mathrm{SCP}_{\mathrm{B}}\left(10^{-5} \mathrm{M}\right)$ increased the rate of bursting of the R25/L25 network by nearly 3-fold (Fig. 10). Because the SCPs also excite the R20 cells (Fig. 2D), the possibility existed that some of the effects of bath-applied SCP on the R25/L25 network could be mediated indirectly by cxcitation of the R20 cclls, which in turn could excite the R25/ L25 neurons by releasing a transmitter other than SCP. Four types of evidence are consistent with the hypothesis that SCP can directly excite the R25/L25 network. (1) If one R 20 cell is strongly hyperpolarized by current injection, both R20 cells can be prevented from firing by current spread through the electronic junctions. Under these circumstances, with both $R 20$ cells silent, bath-applied $\mathrm{SCP}_{\mathrm{B}}$ still elicits an increase in bursting of the R25/ L25 network (Fig. 11A). (2) TTX in the bathing medium blocks 
A 1

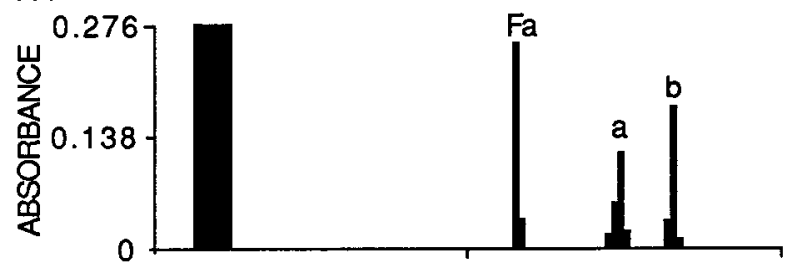

A2

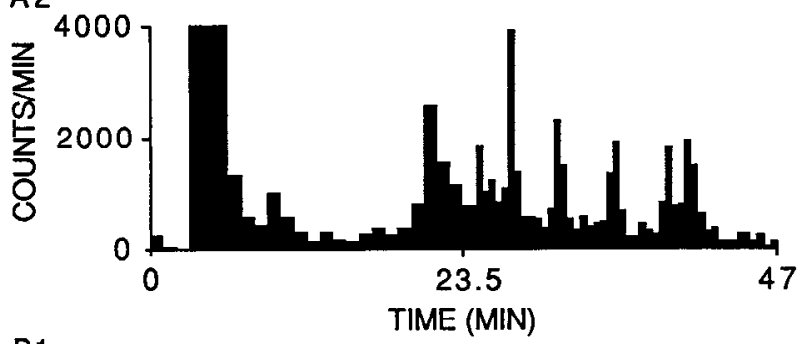

B1

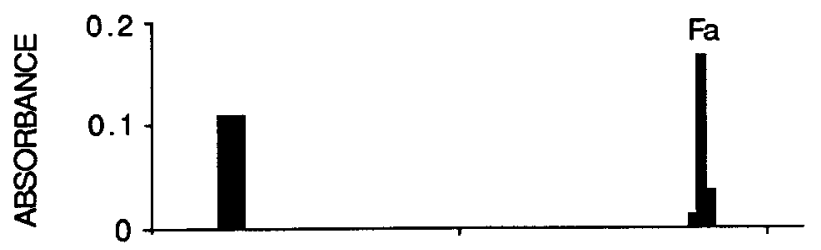

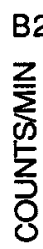

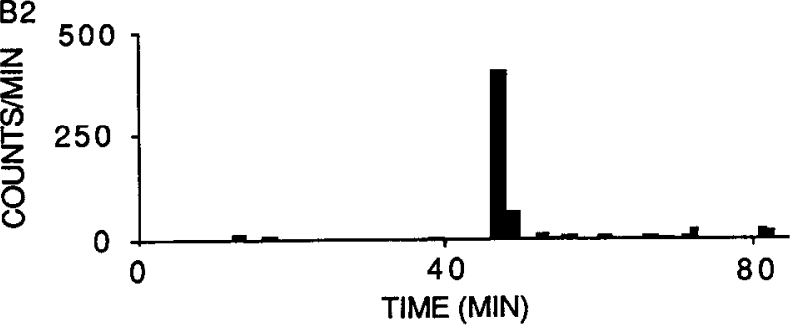

Figure 6. The R20 cells synthesize several methionine-containing, lowmolecular-weight neuropeptides. $A$, Reverse-phase HPLC in the presence of TFA of an extract of 5 pooled R20 neurons that were labeled with ${ }^{35}$ S-methionine. $A 1$, Absorbance profile (at $215 \mathrm{~nm}$ ) of unlabeled synthetic FMRFamide $(\mathrm{Fa}), \mathrm{SCP}_{\mathrm{A}}(a)$ and $\mathrm{SCP}_{\mathrm{B}}(b)$ that were added to the neurons before extraction. $A 2$, Radioactivity detected by scintillation counting of aliquots of samples eluting from HPLC (counts per whole fraction are plotted). Note the peaks of radioactivity that coeluted with FMRFamide $(\mathrm{Fa})$, with $\mathrm{SCP}_{\mathrm{A}}(a)$ and with $\mathrm{SCP}_{\mathrm{B}}(b)$. Material from each of these peaks was subjected to additional chromatographic procedures that are shown in $B$ and in Figure 7. $B$, The R20 cells do not synthesize FMRFamide. Reverse-phase HPLC of the FMRFamide containing peak (peak Fa) from $A$ in the presence of HFBA. B1, Absorbance profile (at $215 \mathrm{~nm}$ ) of unlabeled synthetic FMRFamide. B2, Radioactivity detected by scintillation counting of samples eluting from HPLC. Note that under these chromatographic conditions the elution time of synthetic unlabeled FMRFamide is different from the elution time of radioactivity, although the 2 coeluted when TFA was used as a counterion in $A$.

the action potentials of the neurons of the R25/L25 network, revealing underlying plateau potentials in the R25 and L25 neurons that drive the spontaneously occurring bursts (Fig. $5 A$ ). $\mathrm{SCP}_{\mathrm{B}}$ added in the presence of TTX increases the frequency of these spontaneous plateau potentials (Fig. $5 B$ ). (Although the $\mathrm{R} 20$ cells can generate calcium-mediated action potentials in TTX, they are much less excitable than in normal saline.) (3) $\mathrm{SCP}_{\mathrm{B}}$ puffed onto the $\mathrm{R} 25$ cluster from a micropipette positioned just over the R25 cell bodies and far from the R20 cells elicits excitation of the R25 cluster (Fig. 11B). (4) Bath-applied $\mathrm{SCP}_{\mathrm{B}}$ excites the $R 25$ cells with polysynaptic transmission reduced by bathing the ganglion in high divalent cation solution (Fig. 13D).
A 1
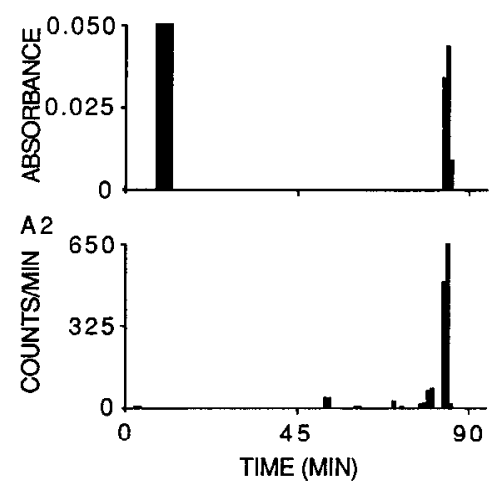

B1
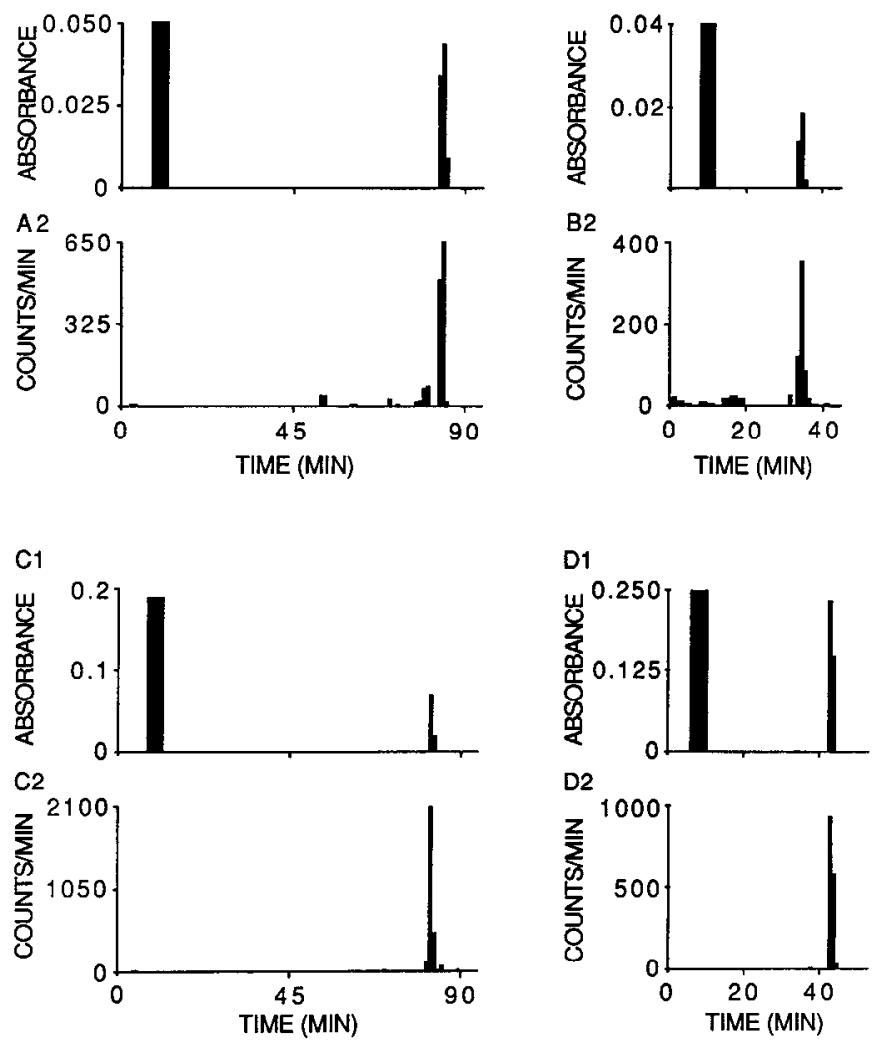

Figure 7. The $\mathrm{R} 20$ cells synthesize $\mathrm{SCP}_{\mathrm{A}}$ and $\mathrm{SCP}_{\mathrm{B}}$. Reverse-phase HPLC of the $\mathrm{SCP}_{\mathrm{A}^{-}}$and $\mathrm{SCP}_{\mathrm{B}}$-containing peaks from Figure $6 A$ in the presence of HFBA and TEA. $A$, Chromatography of the $\mathrm{SCP}_{\mathrm{A}}$-containing peak from Figure $6 A$ in the presence of HFBA. $A 1$, Absorbance profile (at $215 \mathrm{~nm}$ ) of unlabeled synthetic $\mathrm{SCP}_{\mathrm{A}} . A 2$, Radioactivity detected by scintillation counting of aliquots of samples eluting from HPLC (counts per whole fraction are plotted). The synthetic peptide and radioactivity continue to coelute. $B$, Chromatography of the $\mathrm{SCP}_{\mathrm{A}}$-containing peak from $A$ of this figure in the presence of TEA. B1, Absorbance profile (at $215 \mathrm{~nm}$ ) of unlabeled synthetic $\mathrm{SCP}_{\mathrm{A}} . B 2$, Radioactivity detected by scintillation counting of samples eluting from HPLC. Radioactivity and the synthetic $\mathrm{SCP}_{\mathrm{A}}$ continue to coelute in this third stage of chromatography. $C$, Chromatography of the $\mathrm{SCP}_{\mathrm{B}}$-containing peak from Figure $6 A$ in the presence of HFBA. C1, Absorbance profile (at $215 \mathrm{~nm}$ ) of unlabeled synthetic $\mathrm{SCP}_{\mathrm{B}}$. $C 2$, Radioactivity detected by scintillation counting of aliquots of samples eluting from HPLC. Radioactivity and the synthetic $\mathrm{SCP}_{\mathrm{A}}$ continue to coelute. $D$, Chromatography of the $\mathrm{SCP}_{\mathrm{B}}$ containing peak from $C$ of this figure in the presence of TEA. D1, Absorbance profile (at $215 \mathrm{~nm}$ ) of unlabeled synthetic $\mathrm{SCP}_{\mathrm{B}}$. D2, Radioactivity detected by scintillation counting of samples eluting from HPLC. Radioactivity and the synthetic $\mathrm{SCP}_{\mathrm{B}}$ continue to coelute in this final stage of chromatography.

Unlike the response of the R 25 and L25 neurons, the primary responses elicited by $\mathrm{R} 20$ activity in the $\mathrm{RB}$ cells, the $\mathrm{RG}$ cells, and the cells of the branchial ganglion do not appear to be mediated by the release of the SCPs. The RB cells, the RG cells, and the branchial ganglion cells are weakly excited by pharmacological application of the SCPs but strongly inhibited by the R20 cells (Figs. 3, 12). These data suggest that the R20 cells may release other transmitters in addition to the SCPs.

To test the possibility that the effects of the SCPs on the RB, $R G$, and branchial ganglion follower cells might be mediated indirectly by excitation of interneurons in the ganglion, we applied $\mathrm{SCP}_{\mathrm{B}}$ in the presence of high divalent cation solution, in order to raise the threshold for polysynaptic transmission. Under these conditions, the pharmacological actions of $\mathrm{SCP}_{\mathrm{B}}$ on 


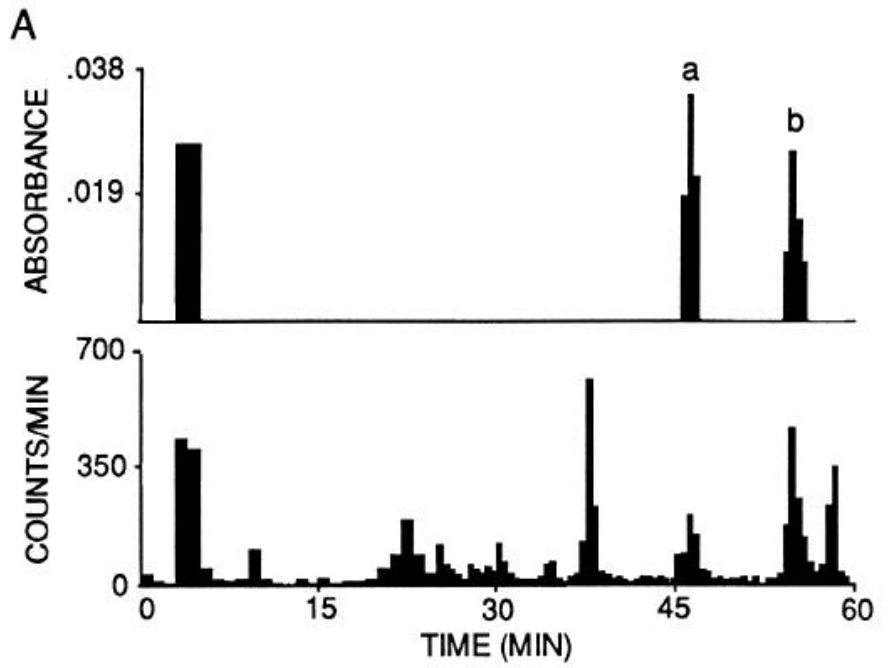

B

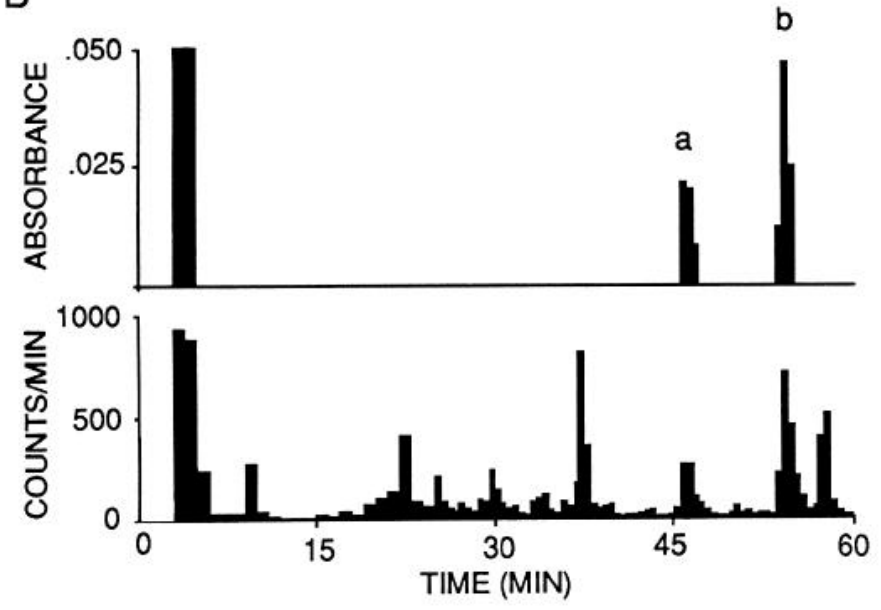

Figure 8. The 2 R20 cells synthesize the same pattern of methioninecontaining peptides. Reverse-phase HPLC in the presence of TFA of extracts of each of 2 R20 neurons taken from the same ganglion after labeling with ${ }^{35} \mathrm{~S}$-methionine. $A$ and $B$ each show the separate data from one of the 2 R20 cells. Absorbance profile (at $215 \mathrm{~nm}$ ) of unlabeled synthetic $\mathrm{SCP}_{\mathrm{A}}(a)$ and $\mathrm{SCP}_{\mathrm{B}}(b)$ that were added to the neurons before extraction is at the top of each data set; radioactivity detected by scintillation counting of samples eluting from HPLC is at the bottom of each set.

the RB, RG, and branchial ganglion cell followers of the R20 cells were eliminated (Fig. 13, $A-C$ ). This blockade of the effect of $\mathrm{SCP}_{\mathrm{B}}$ could be due to blocking of an interneuronal pathway or to direct effects of the divalent cations on the receptors or ion channels in the follower cells. The latter possibility seems unlikely, as the excitatory effects of the SCPs on the R20 cells and on the R25/L25 network are not blocked by the same high divalent cation solution (unpublished results and Fig. 13D). In either case, the data are not consistent with the SCPs mediating the R20 synaptic actions on these follower cells. Figure 14 summarizes the known synaptic connections made by the R20 neurons to identified cells in the branchial and abdominal ganglia, and the pharmacological action of the SCPs on each of the postsynaptic cells.

\section{Discussion}

Function of the R20 cells

The behavioral or physiological context in which the R20 cells are activated in the intact animal remains to be determined.
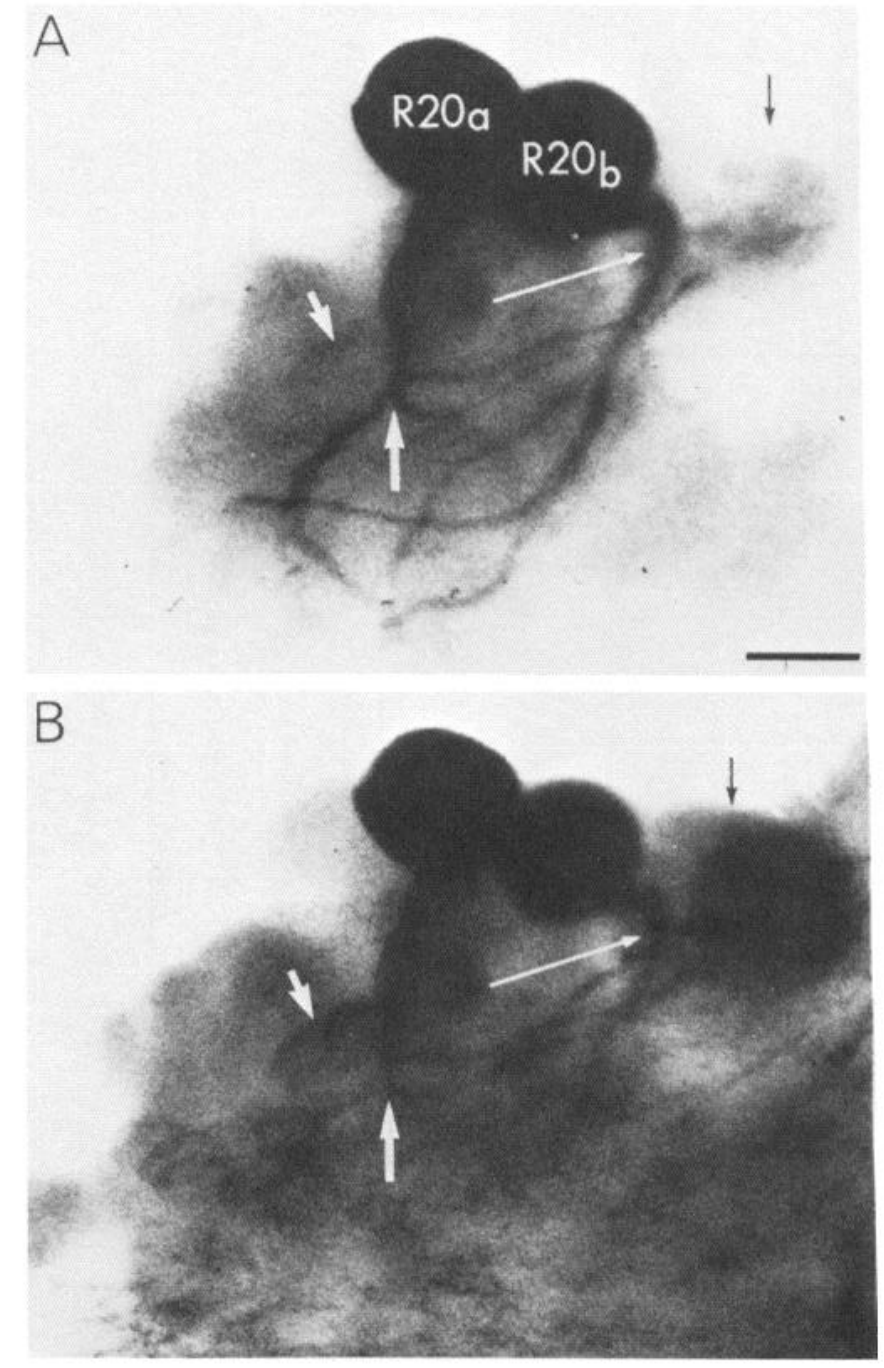

Figure 9. Antibodies to $\mathrm{SCP}_{\mathrm{B}}$ label selectively the R20 cells. Fluorescence micrographs of right dorsocaudal region of abdominal ganglion viewed in whole mount. $A$, With the filter pack set for viewing Lucifer yellow, the 2 R20 cell bodies and processes (white arrows) that were labeled by iontophoretic injection of Lucifer yellow are visible. $B$, Viewing the same field as shown in $A$, but with filter pack set for viewing rhodamine, the $2 \mathrm{R} 20$ cells, as well as one neighboring cell (black arrows), were shown to possess $\mathrm{SCP}_{\mathrm{B}}$ immunoreactivity.

The R20 cells are unusually silent compared with most neurons in the abdominal ganglion. In none of our experiments did they ever fire spontaneously, nor did they receive significant spontaneous or triggered synaptic input in the reduced preparations that we used. Moreover, we were unable to elicit significant excitatory input to the R20 cells by stimulation of identified sensory neurons and interneurons in the ganglion or by stimulation of the peripheral nerves. Tactile or nociceptive stimuli to the tail or to the mantle organs and appetitive (feeding) stimuli to the lips, which triggered biting movements, also were ineffective in exciting the R20 cells. Perhaps these cells normally are activated by changes in such circulating factors as hormones, blood gases, or metabolic products. Further experiments utilizing a more intact preparation will be required to test this hypothesis and to determine the role of the R20 cells in the overall physiological control mechanisms of the animal. It is interesting to note that firing the R20 cells for $30-60 \mathrm{sec}$ at $10 \mathrm{~Hz}$ can mimic the high-frequency, decelerating train of respiratory 


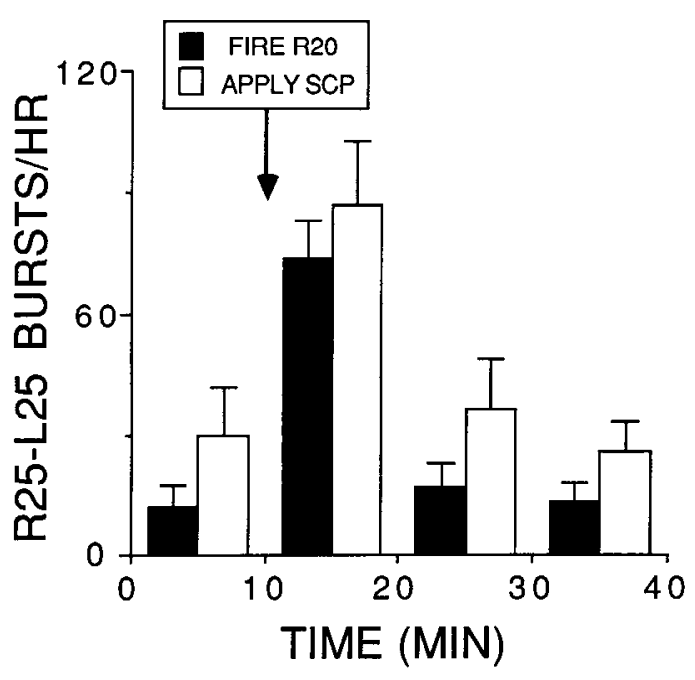

Figure 10. The effects of the R20 cells on the R25/L25 network are mimicked by $\mathrm{SCP}_{\mathrm{B}}$. Activity of the R25/L25 cell network was monitored by recording from an LD or RD follower of the R25 and L25 cells. After a 10 min baseline period, either a single R20 cell was fired for 25 sec at $10 \mathrm{~Hz}$ or a $50 \mu \mathrm{l}$ bolus of $10^{-5} \mathrm{M} \mathrm{SCP}$ was added to the superfusate that was applied to the ganglion. The somewhat longer time course of the SCP effect compared with the R20 effect presumably results because the SCP washout took several minutes. Perfusion rate was $1.5 \mathrm{ml} / \mathrm{min}$, into a bath volume of $5 \mathrm{ml}$. Mean $\pm \mathrm{SEM}, n=4$ for each condition.

pumping episodes, termed a "seizure," that sometimes occurs spontaneously in the intact animal (Kanz and Quast, 1985).

\section{Homology or analogy of the R20 cells to modulatory cells in other gastropods}

The R20 cells share many characteristics with the bilaterally symmetrical pair of ventral white cells (VWCs) in the buccal ganglion of Pleurobranchaea. Like the R20 cells, the VWCs are peptidergic, they increase the frequency of a rhythmic behavior (feeding), and they show pronounced spike broadening during sustained firing (Gillette et al., 1980).

In their lack of spontaneous or elicited activity, the R20 cells resemble another pair of neurons that modulate bursting of gastropod neurons. Pin and Gola $(1983,1984)$ described a pair of electrically coupled interneurons in the nervous system of Helix pomatia that increase the rate of bursting of 2 endogenous bursters: cell $\mathrm{Br}$ (RPA1) in the right parietal ganglion and cell $\mathrm{Br}^{\prime}$ in the visceral ganglion. These coupled interneurons also are thought to be peptidergic (Kononenko and Osipenko, 1986; Pin et al., 1986). Although the identity of their transmitters has not yet been determined, it is unlikely that the pair of interneurons in Helix is homologous to the R20 cells. They are located in the visceral ganglion, which is believed to be homologous to the left caudal quadrant of the abdominal ganglion of Aplysia (Bullock and Horridge, 1965), while the R20 cells are in the right caudal quadrant of the abdominal ganglion.

There is an intriguing resemblance between the $\mathrm{R} 20$ cells and the 2 electrically coupled peptidergic neurons found in Lymnea stagnalis, the RPD2 and VD1 cells. These 2 cells, which are immunoreactive for ACTH (Boer et al., 1979), modulate the activity of interneurons that control the respiratory motoneurons in this freshwater pulmonate (Wilt et al., 1988). Like the R20 cells, the RPD2 and VDl cells send numerous axons to the periphery. However, the VD1 cell is located in the visceral ganglion, and the RPD2 cell is located in the right parietal ganglion, which is thought to be homologous to the right rostral quadrant of the abdominal ganglion in Aplysia.

\section{Transmitters in the $R 20$ cells}

Each of the $2 \mathrm{R} 20$ cells synthesizes $\mathrm{SCP}_{\mathrm{A}}$ and $\mathrm{SCP}_{\mathrm{B}}$ in roughly equal quantities. This stoichiometric relation was to be expected, as Mahon et al. (1985) previously had found that $\mathbf{S C P}_{\mathrm{A}}$ and $\mathrm{SCP}_{\mathrm{B}}$ are derived from a common precursor molecule in neurons B1 and B2 in the buccal ganglia. More generally, the entire HPLC profiles obtained from the $2{ }^{35} \mathrm{~S}$-methionine-labeled R20 cells in a single ganglion were remarkably similar to each other, with several clearly distinguishable peaks that are present in both cells. This close correspondence in peptide synthesis reinforces the impression gained from morphological and electrophysiological data that the 2 R 20 cells have similar, and perhaps identical, functions.

The SCPs are thought to be neuromodulators because they exhibit bioactivity on a number of nerve and muscle cells, they
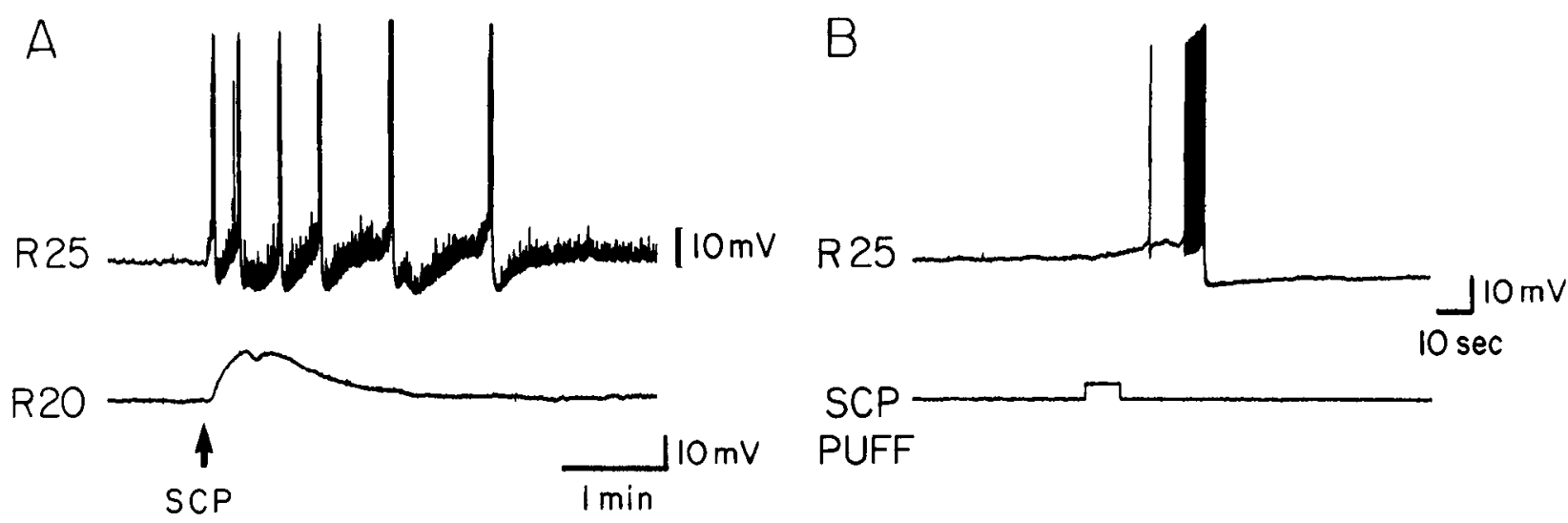

Figure 11. The excitation of the R25/L25 network by SCP can occur independently of activation of the R20 cells. $A$, The increase in bursting activity of the R25/L25 network by bath application of SCP $\left(50 \mu l\right.$ of $10^{-5} \mathrm{M}$ injected into the superfusate) persists when the R20 cells are prevented from firing by current injection into the soma of one of the R20 cells. If the second R20 cell had fired, its action potentials would have been recorded as electrotonic PSPs in the cell that was monitored. $B$, When $\operatorname{SCP}_{\mathrm{A}}\left(5 \times 10^{-4} \mathrm{M}\right)$ is puffed from a micropipette onto the cell bodies of the R25 cluster, a few hundred microns away from the R20 somas, it elicits a population burst monitored in a single R25 cell. 


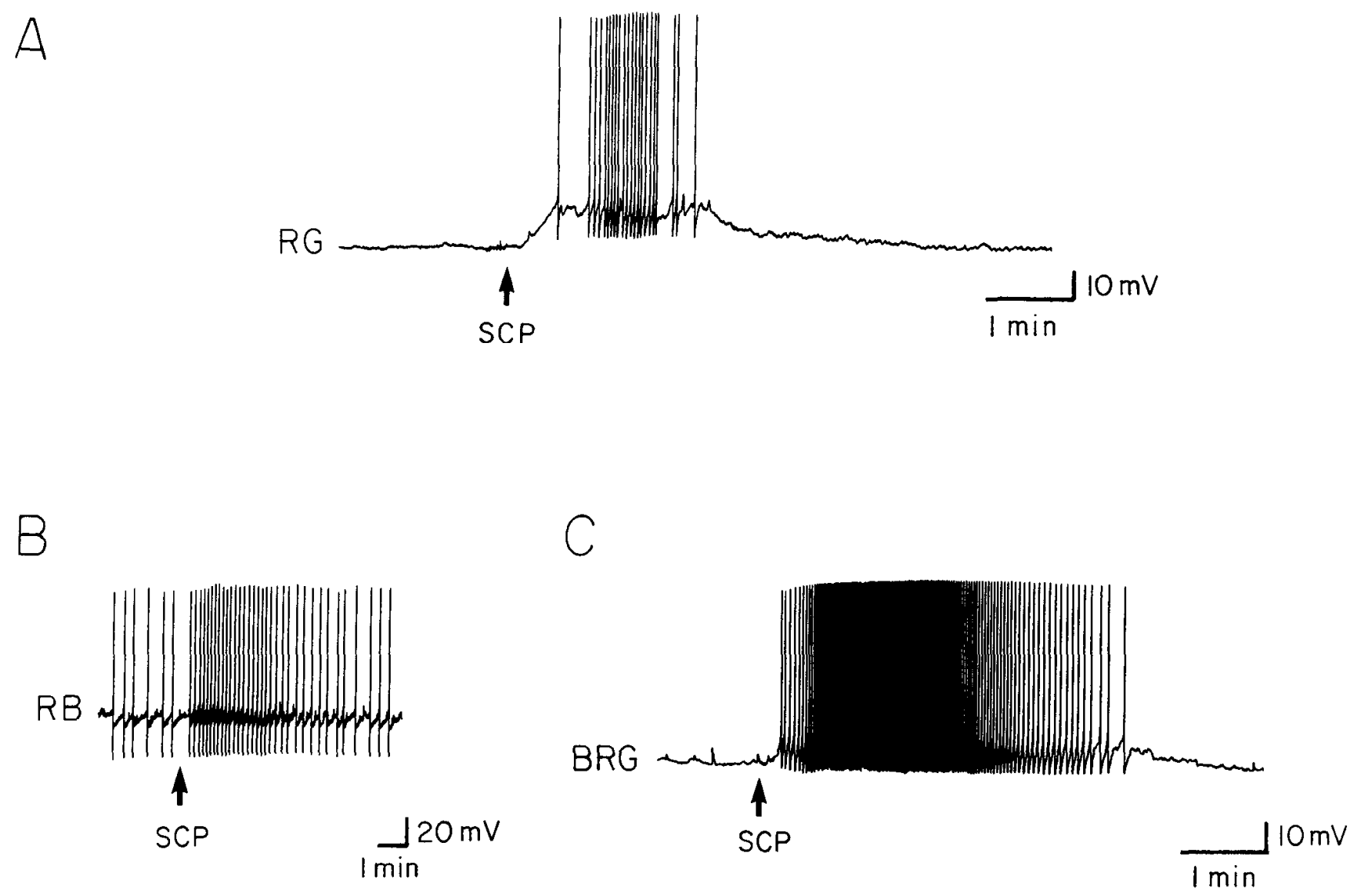

Figure 12. SCP has effects on the RG, RB, and the branchial ganglion (BRG) cells that are opposite in sign to the effects produced by firing the R20 cells (cf. Fig. 3). In all cases, a $50 \mu \mathrm{l}$ bolus of $10^{-5} \mathrm{M} \mathrm{SCP}$, was injected into the superfusate that bathed the ganglion.

A

$R G$
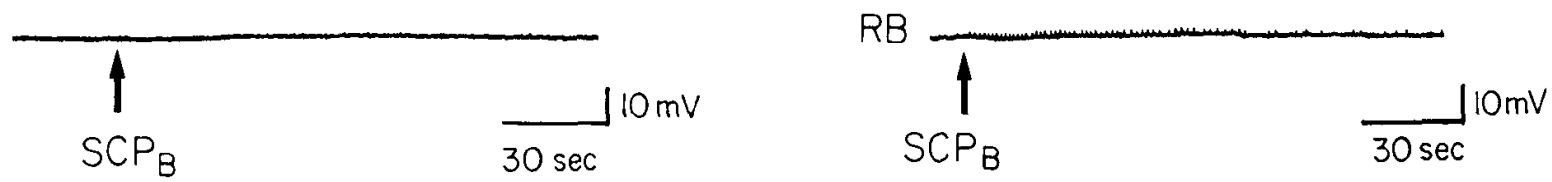

C
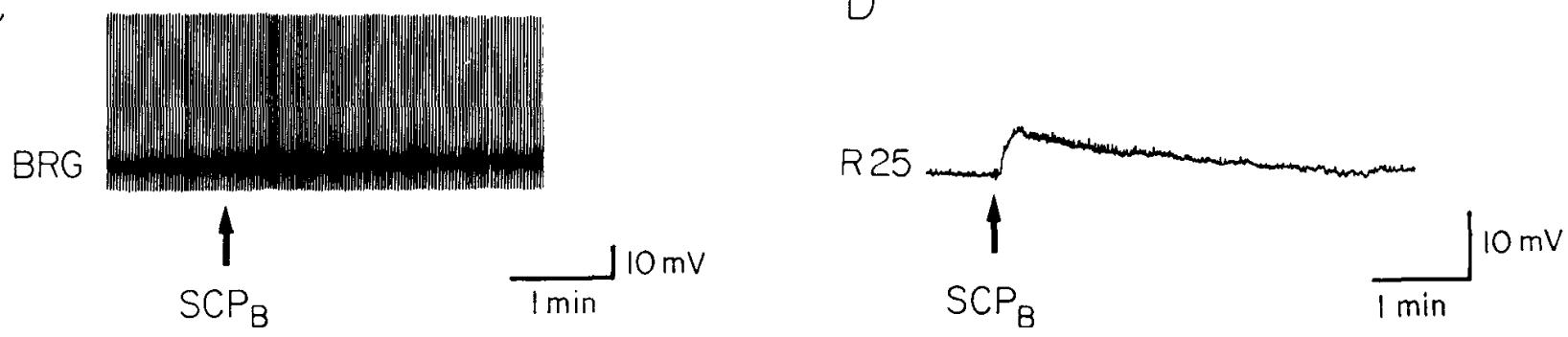

Figure 13. Bathing the preparation in high divalent cation solution blocks the inhibitory effects of $\mathrm{SCP}_{\mathrm{B}}$ on the RB, RG, and BRG cells $(A-C)$, but does not block the excitatory effect of $\mathrm{SCP}_{\mathrm{B}}$ on the cells of the R25/L25 network $(D)$. 


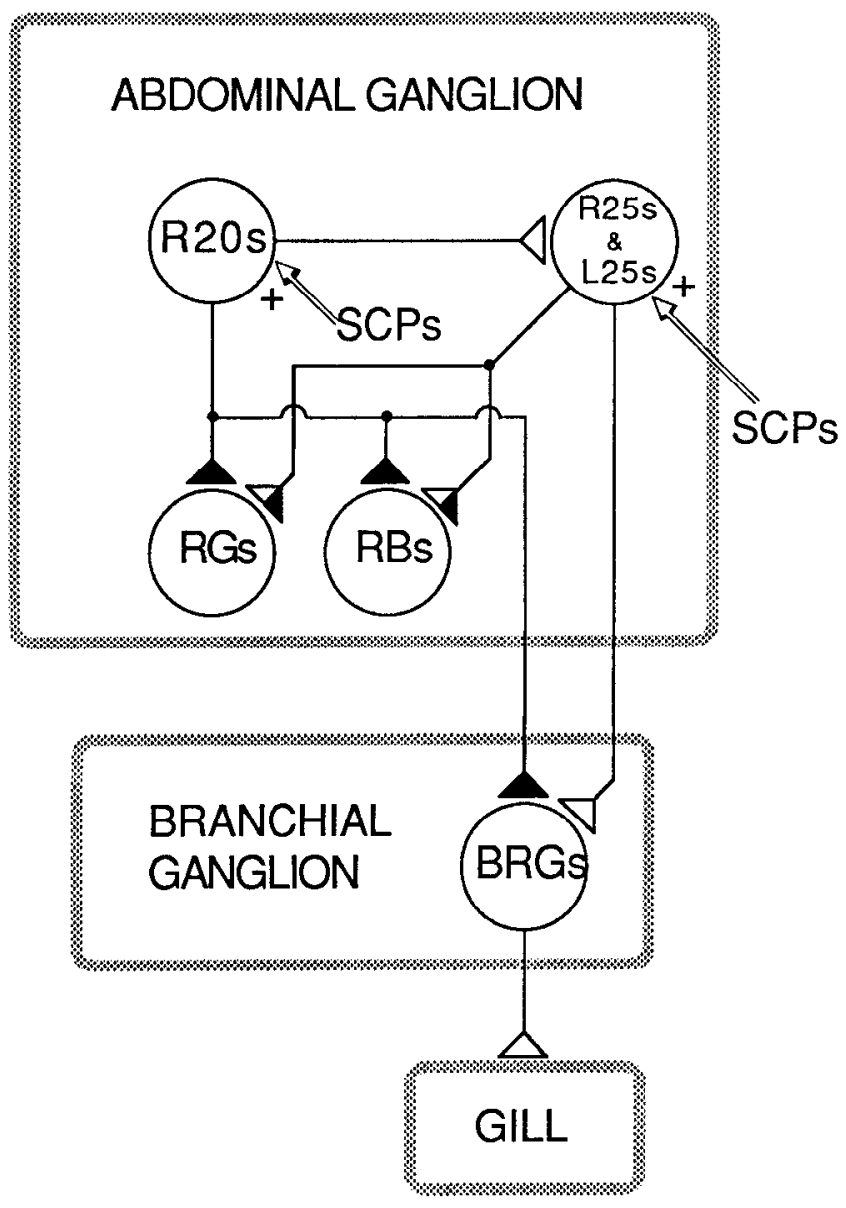

Figure 14. Schematic diagram of the known synaptic connections made by the R20 cells, and the pharmacological actions of the SCPs on the followers of the R 20 cells. All of the synaptic effects shown here persisted in high divalent cation solution. Triangles represent chemical connections: open for excitation, closed for inhibition, open and closed together for conjoint synapses that produce both excitation and inhibition.

are selectively distributed in different neurons in the nervous system (Lloyd, 1986), they are localized to dense-core vesicles (Kreiner et al., 1986; Reed et al., 1988), and they are released by spike activity in a $\mathrm{Ca}^{2+}$-dependent manner (Lloyd et al., 1986). Two types of evidence suggest that the R20 cells may use the SCPS as a transmitter for at least some of their synaptic actions. (1) They both synthesize $\mathrm{SCP}_{\mathrm{A}}$ and $\mathrm{SCP}_{\mathrm{B}}$. (2) The SCPs mimic the effects of the R20 cells on the R25/L25 network. In interpreting the data on the synaptic actions of the R20 cells and the pharmacological actions of SCP, one must consider that it is extremely difficult to rule out definitively the possibility that indirectly mediated synaptic actions may contribute to some of the observed effects. The use of TTX or high divalent cation solution to reduce polysynaptic activity is only a partial solution to this problem. The results shown in Figures $4 A 2$ and $5 A$ illustrate that at least one polysynaptic pathway can be (weakly) activated in high divalent cation solution and that TTX does not eliminate all action potential generation in the abdominal ganglion. Even with these reservations in mind, the bulk of our data lead us to propose that some of the excitatory effects of the R 20 cells on the R25/L25 network may be mediated by the SCPs. Though still incomplete, our data provide the best evidence to date for an identified SCPergic central synapse.
The SCPs do not mimic the actions of the R20 cells on the RB, RG, or BRG ganglion cells (Fig. 14), all of which are excited weakly by the SCPs but inhibited strongly by the R20 cells. Because the excitatory effects of the R 20 cells on these 3 types of cells are blocked by high divalent cation solutions, they are likely to be polysynaptic. One interpretation of these results is that excitation of the R25/L25 network by the R20 cells is produced by the release of the SCPs, but the R20 cells also release at least one additional type of neurotransmitter. For example, some of the uncharacterized radioactive peaks in the HPLC profiles of ${ }^{35}$ S-labeled R20 cells may be neuropeptides. In addition, the $\mathrm{R} 20$ cells also may utilize either a neuropeptide that lacks methionine or a small molecule transmitter, neither of which would have been detected by our HPLC analysis. The fact that the SCPs mimic the excitatory effects of the R20 cells on the R25/L25 cells but not the inhibitory effects of the R20 cells on the RB, RG, and BRG cells could thus be explained by making the following 3 assumptions: (1) the R20 cells use the SCPs and one additional type of transmitter; (2) the R25/L25 cells have excitatory receptors for SCP, but no receptors for the second transmitter type; (3) the RB, RG, and BRG cells have inhibitory receptors for the second transmitter type, but no SCP receptors.

A large amount of anatomical, biochemical, physiological, and pharmacological data supports the hypothesis that the SCPs are used extensively by neurons that exert central and peripheral control over feeding behavior in a number of species in at least 2 subclasses of gastropod molluscs (Murphy et al., 1985; Cropper et al., 1987b; Lloyd et al., 1988; Prior and Watson, 1988; Willows et al., 1988). On the other hand, earlier work had demonstrated that the SCPS are present in all of the central ganglia of Aplysia (Lloyd et al., 1985) and that a number of neurons and muscles not directly involved in feeding behavior have receptors for the SCPs (Abrams et al., 1984; Lloyd et al., 1985; Richmond et al., 1986; Lukowiak and Colmers, 1987). Our results provide additional evidence that in Aplysia the SCPs may act as transmitters for neurons not directly involved in the control of feeding.

All of the pharmacological and synaptic actions described for the SCPs so far have been excitatory, with one exception-the inhibition of circular esophageal muscle in Aplysia (Lloyd et al., 1988). Given the extensive innvervation of Aplysia gut by an enteric nervous system, it is not clear whether the actions of the SCPs on this muscle are direct or indirect. In any event, the preponderance of evidence from 5 species suggests that the SCPS exert mostly excitatory actions in gastropods (Abrams et al., 1984; Lloyd et al., 1984, 1985, 1988; Coates and Bulloch, 1985; Murphy et al., 1985; Lloyd, 1986; Richmond et al., 1986; Lukowiak and Colmers, 1987; Sossin et al., 1987; Taussig and Scheller, 1987; Acosta-Urquidi, 1988; Prior and Watson, 1988; Willows et al., 1988). Given that the slow actions of the SCPs are likely to be mediated by one or more second-messenger systems, it would be surprising were such a generalization shown to hold for all SCPergic cells. Nevertheless, our evidence in support of the hypothesis that the SCPs mediate the excitatory modulatory actions of the R 20 cells on the R25/L25 network adds further weight to the empirical data suggesting that the SCPs are used primarily for excitatory modulation.

\section{References}

Abrams, T. W., V. F. Castellucci, J. S. Camardo, E. R. Kandel, and P. E. Lloyd (1984) Two endogenous neuropeptides modulate the gill 
and siphon withdrawal reflex in Aplysia by presynaptic facilitation involving cAMP-dependent closure of a serotonin-sensitive potassium channel. Proc. Natl. Acad. Sci. USA 81: 7956-7960.

Acosta-Urquidi, J. (1988) Modulation of calcium current and diverse $\mathrm{K}^{+}$currents in identified Hermissenda neurons by small cardioactive peptide B. J. Neurosci. 8: 1694-1703.

Alevizos, A., K. R. Weiss, and J. Koester (1988) The R20 neurons, which modulate respiratory pumping in Aplysia, synthesize SCP. Soc. Neurosci. Abstr. 14: 536.

Boer, H. H., L. P. C. Schot, E. W. Roubos, A. ter Maat, J. C. Lodder, and D. Reichelt (1979) ACTH-like immunoreactivity in two electrotonically coupled giant neurons in the pond snail Lymnea stagnalis. Cell Tissue Res. 202: 231-240.

Brown, R. O., D. Gusman, A. I. Basbaum, and E. Mayeri (1985) Identification of Aplysia neurons containing immunoreactive FMRFamide. Neuropeptides 6: 517-526.

Bullock, T. H., and G. A. Horridge (1965) Structure and Function of the Nervous System in Invertebrates, Vol. 2, p. 1263, Freeman, San Francisco.

Byrne, J. (1983) Identification and initial characterization of a cluster of command and pattern-generating neurons underlying respiratory pumping in Aplysia californica. J. Neurophysiol. 49: 491-508.

Byrne, J., and J. Koester (1978) Respiratory pumping: Neuronal control of a centrally commanded behavior in Aplysia. Brain Res. 143: 87-105.

Coates, C. J., and A. G. M. Bulloch (1985) Synaptic plasticity in the molluscan peripheral nervous system: Physiology and role for peptides. J. Neurosci. 5: 2677-2684.

Croll, R. P. (1985) Sensory control of respiratory pumping in Aplysia californica. J. Exp. Biol. 117: 15-27.

Cropper, E. C., P. E. Lloyd, W. Reed, R. Tenenbaum, I. Kupfermann, and K. R. Weiss (1987a) Multiple neuropeptides in cholinergic motor neurons of Aplysia: Evidence for modulation intrinsic to the motor circuit. Proc. Natl. Acad. Sci. USA 84: 3486-3490.

Cropper, E. C., R. Tenenbaum, M. A. Kolks, I. Kupfermann, and K. R. Weiss (1987b) Myomodulin: A bioactive neuropeptide present in an identified cholinergic buccal motor neuron of Aplysia. Proc. Natl. Acad. Sci. USA 84: 5483-5486.

Cropper, E. C., M. W. Miller, R. Tenenbaum, M. A. Gawinowicz Kolks, I. Kupfermann, and K. R. Weiss (1988) Structure and action of buccalin: A modulatory neuropeptide localized to an identified small cardioactive peptide-containing cholinergic motor neuron of Aplysia californica. Proc. Nat1. Acad. Sci. USA 85: 6177-6181.

Eberly, L. B., and H. M. Pinsker (1984) Neuroethological studies of reflex plasticity in intact Aplysia. Behav. Neurosci. 98: 609-630.

Eberly, L., J. Kan $\measuredangle$, C. Taylor, and H. Pinsker (1981) Environmental modulation of a central pattern generator in freely behaving Aplysia. Behav. Neural Biol. 32: 21-34.

Eisenstadt, M., J. E. Goldman, E. K. Kandel, H. Koike, J. Koester, and J. H. Schwartz (1973) Intrasomatic injection of radioactive precursors for studying transmitter synthesis in identified neurons of Aplysia californica. Proc. Natl. Acad. Sci. USA 70: 3371-3375.

Frazier, W. T., E. R. Kandel, I. Kupfermann, R. Waziri, and R. E. Coggeshall (1967) Morphological and functional properties of identified neurons in the abdominal ganglion of Aplysia californica. $\mathbf{J}$ Neurophysiol. 30: 1288-1351.

Frost, W. N. (1987) Mechanisms Contributing to Short- and LongTerm Sensitization in Aplysia. Ph.D. Dissertation, Columbia University.

Gillette, R., M. U. Gillette, and W. J. Davis (1980) Action potential broadening and endogenously sustained bursting are substrates of command ability in a feeding neuron of Pleurobranchaea. J. Neurophysiol. 43: 669-685.

Hawkins, R. D., G. A. Clark, and E. R. Kandel (1985) Operant conditioning and differential classical conditioning of gill withdrawal in Aplysia. Soc. Neurosci. Abstr. 11: 796.

Hening, W. A. (1982) Central Generation and Coordination of a Complex Behavioral Sequence in Aplysia californica: Locomotion and Respiratory Pumping. Ph.D. Dissertation, New York University.

Kandel, E. R., W. T. Frazier, R. Waziri and R. E. Coggeshall (1967) Direct and common connections among identified neurons in Aplysia. J. Neurophysiol. 30: 1352-1376.

Kanz, J. E., and W. D. Quast (1985) Description of a newly-discovered spontaneous behavior, "Respiratory Pumping Seizure," in Aplysia. Soc. Neurosci. Abstr. 11: 268.
Kanz, J. E., and W. D. Quast (1986) Effects of hypoxia and anoxia on respiratory pumping in Aplysia. Am. Zool. 26: A50.

Koch, V. T., J. Koester, and K. R. Weiss (1984) Neuronal mediation of cardiovascular effects of food arousal in Aplysia. J. Neurophysiol. 51: $126-135$.

Koester, J. (1983) Respiratory pumping in Aplysia is controlled by two coupled clusters of interneurons. Soc. Neurosci. Abstr. 9: 542.

Koester, J., and E. R. Kandel (1977) Further identification of neurons in the abdominal ganglion of Aplysia using behavioral criteria. Brain Res. 121: 1-20.

Koester, J., and U. T. Koch (1987) Neural control of the circulatory system of Aplysia. Experientia 43: 972-980.

Koester, J., N. Dieringer, and D. E. Mandelbaum (1979) Cellular neuronal control of molluscan heart. Am. Zool. 19: 103-116.

Kononenko, N. I., and O. N. Osipenko (1986) A study of the connection between the interneuron initiating pacemaker activity in a bursting neuron and the bursting neuron of the snail Helix pomatia. Cell. Mol. Neurobiol. 6: 177-190.

Kreiner, T., W. Sossin, and R. H. Scheller (1986) Localization of Aplysia neurosecretory peptides to multiple populations of dense core vesicles. J. Cell Biol. 102: 769-782.

Kupfermann, I., and E. R. Kandel (1969) Neuronal controls of a behavioral response mediated by the abdominal ganglion of Aplysia. Science 164: 847-850.

Kurokawa, M., and K. Kuwasawa (1985) Electrophysiological studies on the branchial ganglion in the opisthobranch mollusks (Aplysia and Dolabella). J. Comp. Physiol. 156: 35-44.

Kurokawa, M., and K. Kuwasawa (1988) Multimodal inhibitory innervation of the gill of Aplysia juliana. J. Comp. Physiol. A 162: 533541.

Lehman, H. K., D. A. Price, and M. J. Greenberg (1984) The FMRFamide-like neuropeptide of Aplysia is FMRFamide. Biol. Bull. 167: $460-466$.

Lloyd, P. E. (1986) The small cardioactive peptides: A class of modulatory neuropeptides in Aplysia. TINS 9: 428-431.

Lloyd, P. E., I. Kupfermann, and K. R. Weiss (1984) Evidence for parallel actions of a molluscan neuropeptide and serotonin in mediating arousal in Aplysia. Proc. Natl. Acad. Sci. USA 81: 2934-2937.

Lloyd, P. E., A. C. Mahon, I. Kupfermann, J. L. Cohen, R. H. Scheller, and K. R. Weiss (1985) Biochemical and immunocytological localization of molluscan small cardioactive peptides in the nervous system of Aplysia californica. J. Neurosci. 5: 1851-1861.

Lloyd, P. E., S. Schacher, I. Kupfermann, and K. R. Weiss (1986) Release of neuropeptides during intracellular stimulation of single identified Aplysia neurons in culture. Proc. Natl. Acad. Sci. USA 83 : 9794-9798.

Lloyd, P. E., I. Kupfermann, and K. R. Weiss (1987) Sequence of small cardioactive peptide A: A second member of a class of neuropeptides in Aplysia. Peptides 8: 179-184.

Lloyd, P. E., I. Kupfermann, and K. R. Weiss (1988) Central peptidergic neurons regulate gut motility in Aplysia. J. Neurophysiol. 59: 1613-1626.

Longley, R. D., and A. J. Longley (1986) Serotonin immunoreactivity of neurons in the gastropod Aplysia californica. J. Neurobiol. 17:339358.

Lukowiak, K., and W. F. Colmers (1987) Endogenous peptides work at multiple sites in the nervous system in the control of gill behaviors in Aplysia. Reg. Peptides 17: 99-109.

Mahon, A. C., P. E. Lloyd, K. R. Weiss, I. Kupfermann, and R. H. Scheller (1985) The small cardioactive peptides A and B of Aplysia are derived from a common precursor molecule. Proc. Natl. Acad. Sci. USA 82: 3925-3929.

Mayeri, E., J. Koester, I. Kupfermann, G. Liebeswar, and E. R. Kandel (1974) Neural control of circulation in Aplysia. I. Motoneurons. J. Neurophysiol. 37: 458-475.

Morris, H. R., M. Panico, A. Karplus, P. E. Lloyd, and B. Riniker (1982) Elucidation by FAB-MS of the structure of a new cardioactive peptide from Aplysia. Nature 300: 643-645.

Murphy, A. D., K. Lukowiak, and W. K. Stell (1985) Peptidergic modulation of patterned motor activity in identified neurons of Helisoma. Proc. Natl. Acad. Sci. USA 82: 7140-7144.

Pin, T., and M. Gola (1983) Two identified interneurons modulate the firing pattern of pacemaker bursting cells in Helix. Neurosci. Lett. 37: $117-122$.

Pin, T., and M. Gola (1984) Axonal mapping of neurosecretory Helix 
bursting cells. Comp. Biochem. Physiol. 78A: 637-649.

Pin, T., H. Darbon, G. Jacquet, and M. Gola (1986) Modulation of bursting activity of helix neurosecretory bursting cells by an endogenous peptide. Neurosci. Lett. S26: S326.

Pinsker, H., I. Kupfermann, V. F. Castellucci, and E. R. Kandel (1970) Habituation and dishabituation of the gill-withdrawal reflex in Aplysia. Science 167: 1740-1742.

Prior, D. J., and W. H. Watson III (1988) The molluscan neuropeptide, $\mathrm{SCP}_{\mathrm{B}}$, increases the responsiveness of the feeding motor program of Limax maximus. J. Neurobiol. 19: 87-105.

Rao, G., C. A. Barnes, and B. L. McNaughton (1986) Intracellular fluorescent staining with carboxyfluorescein: A rapid and reliable method for quantifying dye-coupling in mammalian central nervous system. J. Neurosci. Methods 16: 251-263.

Reed, W., K. R. Weiss, P. E. Lloyd, I. Kupfermann, M. Chen, and C. H. Bailey (1988) Association of neuroactive peptides with the protein secretory pathway in identified neurons of Aplysia californica: Immunolocalization of $\mathrm{SCP}_{\mathrm{A}}$ and $\mathrm{SCP}_{\mathrm{B}}$ to the contents of dense core vesicles and the trans face of the Golgi apparatus. J. Comp. Neurol. 272: 358-369.

Richmond, J. E., A. G. M. Bullock, and K. Lukowiak (1986) Pepti- dergic modulation of a neuromuscular junction in Aplysia: Bioactivity and immunocytochemistry. Brain Res. 370: 159-164.

Rothman, B. S., E. Mayeri, R. O. Brown, P. M. Yuan, and J. E. Shively (1983) Primary structure and neuronal effects of $\alpha$-bag cell peptide, a second candidate neurotransmitter encoded by a single gene in bag cell neurons of Aplysia. Proc. Natl. Acad. Sci. USA 80: 5753-5757.

Sossin, W. S., M. D. Kirk, and R. H. Scheller (1987) Peptidergic modulation of neuronal circuitry controlling feeding in Aplysia. $\mathrm{J}$. Neurosci. 7: 671-681.

Taussig, R., and R. H. Scheller (1987) Modulation of ionic currents in the identified motorneuron B15 of Aplysia by $5-\mathrm{HT}, \mathrm{SCPb}$, and FMRFamide. Soc. Neurosci. Abstr. 13: 40.

Walters, E. T., and M. T. Erickson (1986) Directional control and the functional organization of defensive responses in Aplysia. J. Comp. Physiol. A 159: 339-351.

Willows, A. O. D., P. E. Lloyd, and B. P. Masinovsky (1988) Multiple transmitter neurons in Tritonia. III. Modulation of central pattern generator controlling feeding. J. Neurobiol. 19: 69-86.

Wilt, G. van der, M. van der Roest, and C. Janse (1988) The role of two peptidergic neurons in modulation of respiratory behaviour in the pond snail Lymnea stagnalis. Symp. Biol. Hung. 26: 377-386. 